\title{
Diurnal variations of ambient particulate wood burning emissions and their contribution to the concentration of Polycyclic Aromatic Hydrocarbons (PAHs) in Seiffen, Germany
}

\author{
L. Poulain ${ }^{1}$, Y. Iinuma ${ }^{1}$, K. Müller ${ }^{1}$, W. Birmili ${ }^{1}$, K. Weinhold ${ }^{1}$, E. Brüggemann ${ }^{1}$, T. Gnauk ${ }^{1}$, A. Hausmann ${ }^{2}$, \\ G. Löschau ${ }^{2}$, A. Wiedensohler ${ }^{1}$, and H. Herrmann ${ }^{1}$ \\ ${ }^{1}$ Leibniz-Institut für Troposphärenforschung, Permoserstr. 15, 04318 Leipzig, Germany \\ ${ }^{2}$ Sächsisches Landesamt für Umwelt, Landwirtschaft und Geologie (LfULG) Pf 5401 37, 01311 Dresden, Germany
}

Received: 5 April 2011 - Published in Atmos. Chem. Phys. Discuss.: 13 April 2011

Revised: 26 October 2011 - Accepted: 29 November 2011 - Published: 16 December 2011

\begin{abstract}
Residential wood burning is becoming an increasingly important cause of air quality problems since it has become a popular source of alternative energy to fossil fuel. In order to characterize the contribution of residential wood burning to local particle pollution, a field campaign was organized at the village of Seiffen (Saxony, Germany). During this campaign, an Aerosol Mass Spectrometer (AMS) was deployed in parallel to a $\mathrm{PM}_{1}$ high volume filter sampler. The AMS mass spectra were analyzed using Positive Matrix Factorization (PMF) to obtain detailed information about the organic aerosol (OA). Biomass-burning organic aerosol (BBOA), Hydrocarbon-like organic aerosol (HOA), and Oxygenated Organic Aerosol (OOA) were identified and represented $20 \%, 17 \%$ and $62 \%$ of total OA, respectively. Additionally, Polycyclic Aromatic Hydrocarbons (PAH) were measured by the AMS with an average concentration of $10 \mathrm{ng} \mathrm{m}^{-3}$ and short term events of extremely high PAH concentration (up to $500 \mathrm{ng} \mathrm{m}^{-3}$ ) compared to the mean PAH value were observed during the whole measurement period. A comparison with the results from $\mathrm{PM}_{1}$ filter samples showed that the BBOA factor and the AMS PAH are good indicators of the total concentration of the different monosaccharide anhydrides and PAH measured on the filter samples. Based on its low correlation with $\mathrm{CO}$ and the low car traffic, the HOA factor was considered to be related to residential heating using liquid fuel. An influence of the time of the week (week vs. weekend) on the diurnal profiles of the dif-
\end{abstract}

Correspondence to: H. Herrmann (herrmann@tropos.de) ferent OA components was observed. The weekdays were characterized by two maxima; a first one early in the morning and a stronger one in the evening. During the weekend days, the different OA components principally reached only one maximum in the afternoon. Finally, the PAH emitted directly from residential wood combustion was estimated to represent $1.5 \%$ of the total mass of the BBOA factor and around $62 \%$ of the total PAH concentration measured at Seiffen. This result highlights the important contribution of residential wood combustion to air quality and PAH emissions at the sampling place, which might have a significant impact on human health. Moreover, it also emphasizes the need for a better time resolution of the chemical characterization of toxic particulate compounds in order to provide more information on variations of the different sources through the days as well as to better estimate the real human exposure.

\section{Introduction}

Fine particulate pollution is suspected to directly affect mortality and morbidity (Pope, 2000; Ostro et al., 2007; Gurjar et al., 2010). Identifying the different sources of these fine particles is an important challenge in order to better estimate their impact on human health. It is well known that during winter time, residential wood combustion is an important local source of particles which directly influences local to regional air quality (Naeher et al., 2007). In the US, the particulate emission of residential wood combustion was estimated around $1.1 \times 10^{6} \mathrm{tyr}^{-1}$ of particulate matter (PM) (Nolte et al., 2001) and measurements made at different

Published by Copernicus Publications on behalf of the European Geosciences Union. 
locations demonstrated that residential wood combustion can contribute significantly to the total PM mass fraction and/or organic aerosol (OA) fraction at rural and/or urban locations. For example, the contribution of residential wood combustion to total $\mathrm{PM}_{1}$ organic fraction was estimated around 37$68 \%$ depending on the model used in the city of Grenoble (France, Favez et al., 2010), 35-40\% in the urban background of Zurich (Switzerland, Lanz et al., 2010), $79 \%$ in the city of Prague (Czech Republic, Saarikoski et al., 2008), around $50 \%$ of the $\mathrm{PM}_{10}$ mass in southwestern Germany (Bari et al., 2009), $10 \%$ of $\mathrm{PM}_{2.5}$ in Vindingen (Denmark, Glasius et al., 2008), and 44-57\% of the total mass concentration in wintertime in the size range 25-606 $\mathrm{nm}$ in Lycksele (Sweden, Krecl et al., 2008). In an overview of central Europe measurements, the estimated contribution of biomass burning aerosol to total $\mathrm{PM}_{1}$ organic aerosol ranged from $17 \%$ to $49 \%$ during winter time (Lanz et al., 2010).

For several years, wood combustion has been considered to be a good alternative to fossil fuel for domestic heating. A pragmatic reason is the increasing price of coal and oil. A more strategic motivation is increasing the interest in the development of renewable energy technologies to decrease greenhouse gas emission. This is part of a global policy to reduce the human carbon footprint. Since the Kyoto Protocol has been accepted in 1997, the European Union intends to reduce its greenhouse gas emissions by at least $20 \%$ between 1990 and 2020 (EU, 2007). One approach employed to reach this goal is to promote wood combustion. For example, in the state of Saxony (Germany), the number of wood stoves $(<15 \mathrm{~kW})$ increased by a factor close to 8 between 2002 and 2006 and the consumption of wood for residential heating was estimated around $8000 \mathrm{TJ}$ in 2007 (Hausmann, 2010), illustrating the renewal of interest for this energy.

Even though epidemiological observations demonstrated a direct contribution of wood smoke to respiratory systems (e.g. Bolling et al., 2009; Naeher et al., 2007; Zelikoff et al., 2002), the health effects of wood burning particles remain unclear. Although wood burning particles did not cause acute airway inflammatory responses in inhalation experiments (Sehlstedt et al., 2010), the authors also reported a protective adaptive response of the distal lung. This confirms that wood combustion particles play a relevant role for indoor as well as outdoor particle exposure in areas in which such combustion processes take place. As other combustion processes, wood burning emissions contain a variety of toxic pollutants and are thus expected to exert adverse effects upon human health. Different studies linked the contribution of wood combustion to an increase in troubles of the cardiovascular system and/or respiratory system (Naeher et al., 2007; Jalava et al., 2010). Several components emitted by wood combustion (e.g. Polycyclic Aromatic Hydrocarbons (PAH)) are considered to be carcinogenic and mutagenic agents (Boström et al., 2002; Lewtas, 2007). Nevertheless, the relation between particle emissions, composition and toxicity is extremely complex and there is a need to better understand the physicochemical properties of wood combustion smoke and to improve the estimation of their biological effects (Bolling et al., 2009; Naeher et al., 2007).

In the context of increasing residential wood combustion emissions and their possible effect on human health, an intensive field study was performed in the small town of Seiffen (Saxony, Germany) during the winter 2007/2008 (Müller et al., 2010). The goal was to evaluate the impact of residential wood combustion on the local aerosol concentration. During winter time, wood combustion is commonly used for house heating in Seiffen (Saxony EPA agency data, Löschau, 2007). Consequently, it is an important and significant source of aerosol particles. In this work, special attention is paid to the characterization of the organic particulate fraction and more specifically to the identification and quantification of the different monosaccharide anhydrides (MA) and PAH compounds. Measurements of MA and PAH were based on the analysis of $24 \mathrm{~h}$ high volume filter samples performed all 4 days. Additionally, in order to follow the diurnal variation with a high time resolution, an Aerodyne Aerosol Mass Spectrometer (AMS) was deployed in January 2008. In this study, we used the AMS to investigate the impact of residential wood combustion on local air quality. These measurements were then compared to the analytical results from filter samples measurements performed simultaneously.

\section{Instrumentation}

\subsection{Sampling station Seiffen}

The sampling location Seiffen is situated in the mid-level mountain area - Erzgebirge $\left(50^{\circ} 38^{\prime} 50^{\prime \prime} \mathrm{N}, 13^{\circ} 27^{\prime} 08^{\prime \prime} \mathrm{E}\right.$, $647 \mathrm{~m}$ a.s.l., approximately 3000 inhabitants) around $50 \mathrm{~km}$ southwest of Dresden, Germany. Wood burning is commonly used for house heating and represents $32 \%$ of the fuel used for small heaters (less than $50 \mathrm{~kW}$ ) and $25 \%$ of the larger ones (up to $500 \mathrm{~kW}$ ) (Saxony EPA agency data, Löschau, 2007).

The AMS instrument was installed in a non-heated room (mean temperature $16^{\circ} \mathrm{C}$ ) located at ground level in a house situated in the centre of the village of Seiffen. To limit contribution of direct traffic emissions, the AMS was installed at around $200 \mathrm{~m}$ away from the main street of the village. The AMS was sampling through a $\mathrm{PM}_{2.5}$ inlet around $2.5 \mathrm{~m}$ above ground level. It is important to mention that the ambient aerosol was not dried prior to its injection into the AMS. Additional filter sampling, gas monitoring and meteorological parameters were performed in front of the house around $10 \mathrm{~m}$ away from the AMS sampling line. 


\subsection{Instrumentation}

\subsubsection{Real time particle characterization}

In order to provide highly time-resolved measurements for chemical particle composition, an Aerodyne High Resolution Time of Flight Aerosol Mass Spectrometer (HR-ToF-AMS, here simply referred to as AMS, DeCarlo et al., 2006) was deployed from 10 January to 2 February 2008. The AMS allows two alternative detection modes: one to measure the particle size distribution (PTOF-mode) and one to measure the chemical composition of the particle (MS-mode). Before detection by the time of flight mass spectrometer, the aerosol non-refractory (NR) components were flash-vaporized by impaction on a heated surface $\left(600^{\circ} \mathrm{C}\right)$ and the vapors were ionized by an electron impact ionization source at $70 \mathrm{eV}$. The AMS is commonly considered to provide non-refractory near $\mathrm{PM}_{1}\left(\mathrm{NR}-\mathrm{PM}_{1}\right.$ ) aerosol mass concentration (Canagaratna et al., 2007). During the measurement period, the AMS was sampled at a typical time resolution of 5 min in " $V$ " mode collecting approximately 6700 samples (4900 during weekdays and 1800 during weekends).

The calculation of the AMS mass concentration required the estimation of the collection efficiency (CE) of the instrument. The $\mathrm{CE}$ value is known to depend on several parameters (Huffman et al., 2005; Matthew et al., 2008), e.g. nitrate content, particle acidity, particle phase (liquid or solid) and relative humidity $(\mathrm{RH})$ in the sampling line. It is considered that in most of the cases, a CE of 0.5 represents a good assumption (e.g. Canagaratna et al., 2007). However, several authors have reported that $\mathrm{CE}$ can increase to 1 when the RH in the sampling line is high (Allan et al., 2004; Sun et al., 2010; Takegawa et al., 2009). As mentioned above, the sampling line was not dried during the present campaign, the outside $\mathrm{RH}$ was around $90 \%$ most of the time and the instrument was installed in a room at around $16^{\circ} \mathrm{C}$. Therefore, based on the difference of temperature between outside and inside, the lowest values of relative humidity could be expected to range between 30 and $40 \%$ in the sampling line. The particles do not instantaneously reach the equilibrium with the RH. Several seconds are needed. For example, based on the comparison of 6 different HTDMAs, Duplissy et al. (2009) suggests that particles have to be dried at least 10 s at $15 \%$ $\mathrm{RH}$ before entering to the first DMA. In our sampling line, the residence time was estimated to be around $10 \mathrm{~s}$. Consequently, the presence of water on the particles could be expected, suggesting a $\mathrm{CE}$ value near 1 . The comparison with the sulfate, nitrate and ammonium concentrations in $\mathrm{PM}_{1}$ filters confirmed this value (see Fig. S1). Thus, a CE value of 1 was applied during the measurement period.

AMS data were analyzed using the standard data analysis software packages (Squirrel version 1.49 and PIKA version 1.08), downloaded from the TOF-AMS-Resources webpage (http://cires.colorado.edu/jimenez-group/ ToFAMSResources/ToFSoftware/). The quantitative re- sults were calculated using the following relative ionization efficiency (RIE) values: 1.4 for organics, 1.2 for sulfate, 1.1 for nitrate, 1.3 for chloride, and 4 for ammonium (Canagaratna et al., 2007).

\subsubsection{Off-line measurements}

Every 4 days and during $24 \mathrm{~h}$ from midnight to midnight (a total sampling volume $720 \mathrm{~m}^{3}$ ), $\mathrm{PM}_{1}$ particles were sampled using a Digitel DHA-80 high volume sampler (Digitel Elektronic AG, Hegnau, Switzerland) and collected on pre-heated $15 \mathrm{~cm}$ diameter quartz fiber filters $\left(105^{\circ} \mathrm{C}, 24 \mathrm{~h}\right.$ and then minimum $48 \mathrm{~h}$ at $20^{\circ} \mathrm{C}$ and $50 \% \mathrm{RH}$ ) (Munktell Filter AB, Falun, Sweden). After sampling, the filters were conditioned at $20{ }^{\circ} \mathrm{C}$ and $50 \% \mathrm{RH}$ for a minimum duration of $48 \mathrm{~h}$ before being weighed by a microbalance Mettler-Toledo (AT 261). According to the analytical method of Brüggemann and Rolle (1998), the filters were then analyzed using Ion Chromatography (Metrohm System 690, Switzerland) for the main water soluble ions $\left(\mathrm{Cl}^{-}, \mathrm{SO}_{4}^{2-}, \mathrm{NO}_{3}^{-}, \mathrm{NH}_{4}^{+}, \mathrm{Na}^{+}, \mathrm{K}^{+}\right.$, $\mathrm{Ca}^{2+}$ and $\left.\mathrm{Mg}^{2+}\right)$. The Organic Carbon to Elemental Carbon ratio (OC/EC) was determined using a carbon analyzer type C-mat 5500 with a NDIR detector (Gnauk et al., 2008). During the measurements period, several field blank filters were collected. They were analyzed 8 times in the laboratory and the mean blank values were subtracted from the concentration of the filter samples. The mean blank values (and the corresponding standard deviations) were $8.90 \pm 0.87 \mu \mathrm{gC}$ for $\mathrm{OC}$ and $1.14 \pm 0.3 \mu \mathrm{gC}$ for $\mathrm{EC}$. The detection limits were $0.31 \mu \mathrm{gC} \mathrm{m}^{-3}$ for $\mathrm{OC}$ and $0.1 \mu \mathrm{gC} \mathrm{m}{ }^{-3}$ for EC. In addition, a Curie Point Pyrolysis Gas Chromatography Mass Spectrometry (CPP-GC-MS, Neusüß et al., 2000) was used to identify and quantify the Polycyclic Aromatic Hydrocarbons (PAH), and a High Performance Anion Exchange Chromatography coupled to Pulsed Amperometric Detector (HPAEC-PAD) was employed to measure monosaccharide anhydrides wood smoke tracers (e.g. Levoglucosan) as previously described by Engling et al. (2006) and Iinuma et al. (2009). Prior to any comparison between the AMS results and the $\mathrm{PM}_{1}$ filters, the AMS data were averaged to match the sampling duration of the filter samples. Although the comparison between AMS and daily $\mathrm{PM}_{1}$ filters was successfully performed for different chemical compounds (see discussion below), it is important to mention that the precision of the resulting linear regression slopes is limited by the restricted number of filter samples.

\subsection{Other measurements}

Standard meteorological variables (Temperature, RH, atmospheric pressure, wind direction, and wind velocity) were also measured continuously with a time resolution of $30 \mathrm{~min}$. The meteorological station was located near the Digitel filter samplers and the measurements were performed on a mast of $8 \mathrm{~m}$ height which was still under roofs level of the 


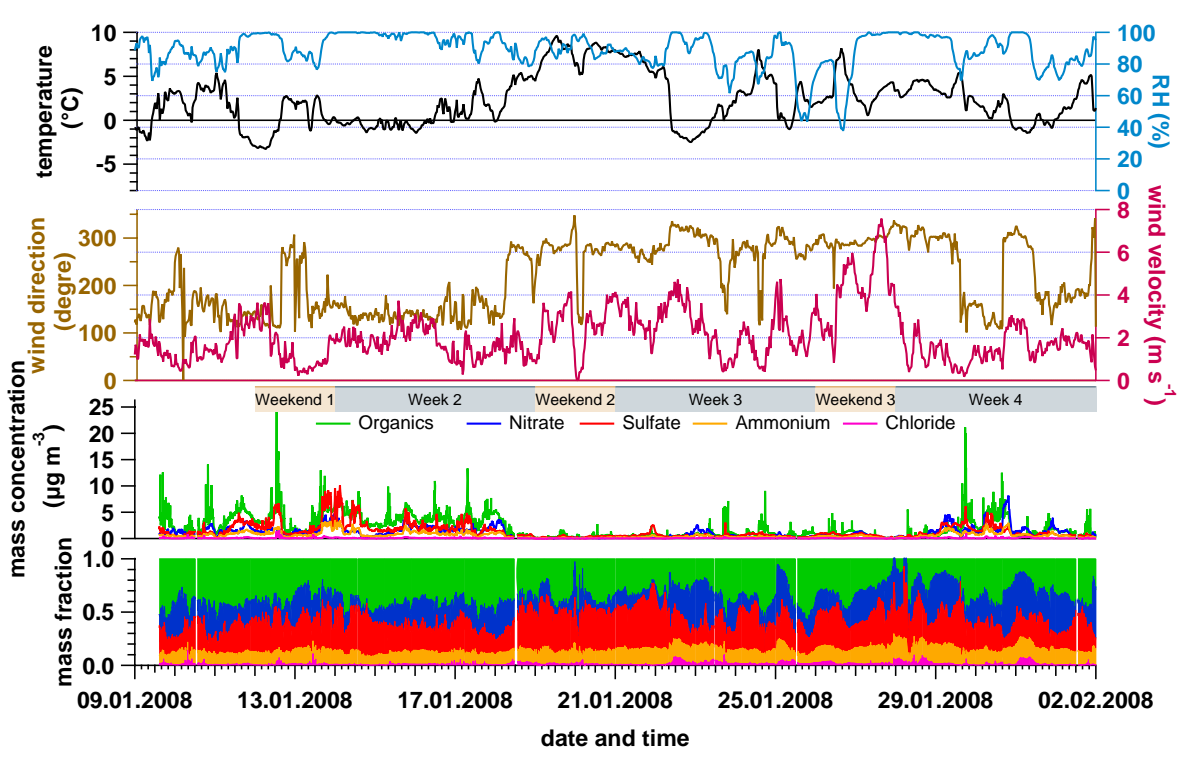

Fig. 1. Campaign overview including local meteorological variables (relative humidity $(\mathrm{RH})$, temperature, wind direction and wind velocity according to a time resolution of $30 \mathrm{~min}$ ), and time series (5 min time resolution) mass concentration and mass fraction of the main NR$\mathrm{PM}_{1}$ aerosol components during the AMS campaign. The number of week and weekend referred to the one used for the diurnal pattern comparison.

surrounding houses. In addition, standard gas phase measurements of $\mathrm{NO}_{\mathrm{x}}$ and $\mathrm{CO}$ (Monitorlabs ML 9830) were performed from the same sample place as the weather station with a time resolution of $30 \mathrm{~min}$.

\section{Results}

\subsection{AMS measurements overview}

Figure 1 provides a basic overview of the local meteorological variables (temperature, $\mathrm{RH}$, wind direction and wind velocity) as well as the mass concentrations of the main NR components (organics, nitrate, sulfate, ammonium and non sea-salt chloride). During winter 2007/08, the temperatures were rather mild and rarely dropped below $0^{\circ} \mathrm{C}$, even at Seiffen's altitude of $647 \mathrm{~m}$. During the AMS sampling period, the mean temperature was $2.3 \pm 2.9^{\circ} \mathrm{C}( \pm 1$ standard deviation) ranging from -3.3 to $+9.6^{\circ} \mathrm{C}$. The ambient relative humidity had a mean value of $89 \pm 10 \%$, ranging from 37.7 to $100 \%$. The wind mainly blew from two directions, southeast ( $47 \%$ of the time) and northwest ( $43 \%$ of the time), with a mean wind velocity of $2.02 \pm 1.16 \mathrm{~m} \mathrm{~s}^{-1}$, ranging from 0 to $7.58 \mathrm{~m} \mathrm{~s}^{-1}$.

The AMS yielded a range of NR-PM $\mathrm{P}_{1}$ mass concentration from 2.6 to $8.0 \mu \mathrm{g} \mathrm{m}^{-3}$. The periods with the highest mass concentration were related to a combination of southeasterly winds and low temperatures, while periods with the lower mass concentrations were related to northwesterly winds and warmer temperatures (Fig. 1). These two cases corresponded to air masses of more continental and more maritime charac- ter, respectively. During the periods of high mass concentrations, a small temperature inversion could be detected between Seiffen and the higher situated Mountain Schwartenberg ( $952 \mathrm{~m}$ a.s.l.). The temperature inversion corresponds to a temperature at Seiffen $0.5^{\circ} \mathrm{C}$ colder than the expected neutral stratification between Seiffen and Schwartenberg. The cool temperatures and the pollution trapping induced by the low winds and the small temperature inversion are thought to be responsible for the local accumulation of the high mass concentrations.

The compositions of the NR-PM 1 mass concentration mainly contained organic aerosol (OA) $(40 \%)$. The mass fraction of sulfate, nitrate, ammonium, and non sea-salt chloride were $26 \%, 21 \%, 12 \%$, and $1 \%$, respectively. As previously mentioned, the nitrate, sulfate and ammonium concentrations measured by the AMS agree with the off-line measurements performed every 4 days (Table 1 and Fig. S1). However, the total masses provided by the two instruments differed strongly. A possible explanation for this discrepancy is the presence of AMS refractory compounds, e.g. black carbon. EC, potassium, calcium, magnesium, and sodium concentrations measured by filter samples represented approximately $1 \mu \mathrm{g} \mathrm{m}^{-3}$ only and therefore cannot explain the entire difference. Another reason might be the presence of water in the filters that artificially enhances the total mass concentration. It is extremely difficult to completely subtract this water contribution from the total particulate mass measured in the filters, even if the filters were conditioned for a minimum duration of $48 \mathrm{~h}$ at $20^{\circ} \mathrm{C}$ and $50 \% \mathrm{RH}$ before being weighed. 
Table 1. Summary of the mean concentrations ( \pm 1 standard deviation) measured on $\mathrm{PM}_{1}$ filter samples and AMS (using the same sampling time and days than $\mathrm{PM}_{1}$ (Mass synchronized to $\mathrm{PM}_{1}$ ) and for the entire campaign).

\begin{tabular}{l|c|ccc}
\hline & $\mathrm{PM}_{1}$ & \multicolumn{3}{|c}{ AMS } \\
\hline & $\begin{array}{c}\text { Mass } \\
\left(\mu \mathrm{g} \mathrm{m}^{-3}\right)\end{array}$ & $\begin{array}{c}\text { Mass synchronized to } \\
\mathrm{PM}_{1}\left(\mu \mathrm{g} \mathrm{m}^{-3}\right)\end{array}$ & $\begin{array}{c}\text { Mass } \\
\left(\mu \mathrm{g} \mathrm{m}^{-3}\right)\end{array}$ & $\begin{array}{c}\text { Mass } \\
\text { fraction }(\%)\end{array}$ \\
\hline Total & $15.18 \pm 6.11$ & $5.67 \pm 4.86$ & $5.05 \pm 4.42$ & \\
Organics & $1.18 \pm 0.55^{*}$ & $2.28 \pm 1.98$ & $2.02 \pm 2.00^{*}$ & 40 \\
Nitrate & $1.27 \pm 0.94$ & $1.18 \pm 1.33$ & $1.05 \pm 1.02$ & 21 \\
Sulfate & $1.59 \pm 0.74$ & $1.43 \pm 1.54$ & $1.29 \pm 1.33$ & 26 \\
Ammonium & $1.08 \pm 0.53$ & $0.68 \pm 0.64$ & $0.61 \pm 0.54$ & 12 \\
Chloride & $0.03 \pm 0.02$ & $0.07 \pm 0.06$ & $0.07 \pm 0.08$ & 1 \\
\hline
\end{tabular}

* The $\mathrm{PM}_{1}$ organics corresponds to the organic carbon (OC) and the AMS organics corresponds to organic mass (OM).

The Organic Mass to Organic Carbon (OM/OC) ratio was calculated according to the elemental analysis method developed by Aiken et al. (2007) and Aiken et al. (2008). In agreement with the dominant primary emissions, a mean value ( \pm standard deviation) of $1.56 \pm 0.13$ was obtained during the measurements. As our filter samples provided directly measurements of the OC concentration and as the AMS provided the $\mathrm{OM}$ concentration, using both instruments allowed us to estimate the OM/OC ratio, too. Using this method, an $\mathrm{OM} / \mathrm{OC}$ ratio of 1.93 was obtained. The difference of these two ratios (1.56 vs. 1.93) might be explained by the uncertainties of each method as well as the limited number of filter samples (a total of 5 samples).

Our measurements covered 3 full weeks (from Monday to Friday, named weeks 2 to 4 ) and 3 weekends (SaturdaySunday, named weekends 1 to 3) (Fig. 1). Additionally, as already mentioned above, the measurements had to be divided into periods of high and low particle concentrations (Fig. 1). Due to the limited number of weekdays and weekends, the large variations in aerosol concentration can strongly affect the resulting mean values and therefore the diurnal profiles of weekdays and weekends. Hence, in the following, the comparison of each of the 3 weeks and weekends is performed individually (Fig. 2).

The comparison of the 3 weeks' diurnal profiles shows that week 3 and 4 were similar and thereby strongly differing from week 2 (Fig. 2). Week 2 was characterized by the highest particle concentrations and did not exhibit clear diurnal variations whereas weeks 3 and 4 showed pronounced diurnal variations of the aerosol compositions (Fig. 2). During these 2 weeks ( 3 and 4), the organics presented 2 maxima: early in the morning around 08:00 and early in the evening between 19:00 and 20:00. Chloride concentration presented also a similar diurnal pattern. The nitrate concentration was lower during day time compared to nighttime, which might confirm the influence of nighttime chemistry and mixed layer height. The sulfate concentration did not manifest a clear profile over the 3 weeks and ammonium ba-
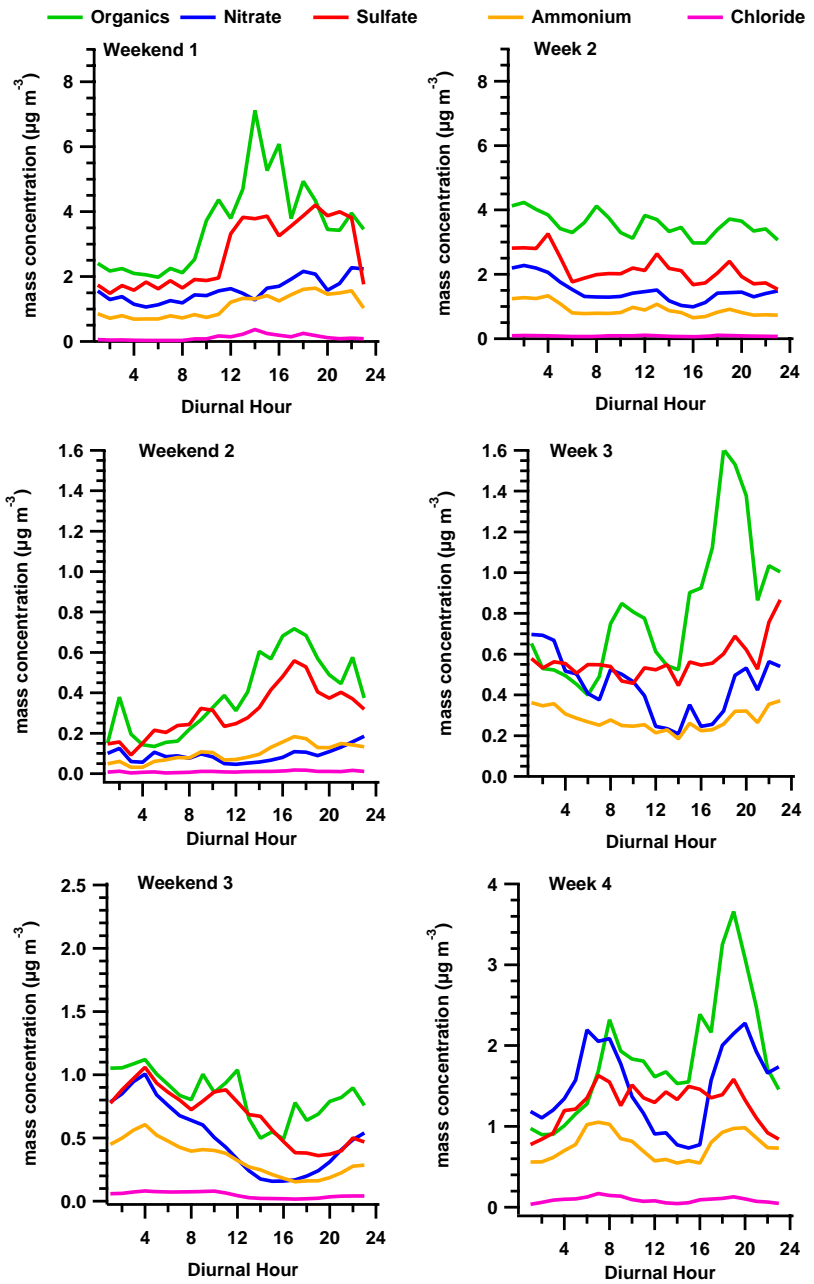

Fig. 2. Diurnal variations of the aerosol composition during weekends (left) and weeks (right). Week and weekend number referred to time periods described in Fig. 1. 
Table 2. Summary of the weather conditions (mean values \pm 1 standard deviation) during each weekdays (Monday to Friday) and weekends (Saturday-Sunday).

\begin{tabular}{lrrrrrrr}
\hline & Week 1 & Weekend 1 & Week 2 & Weekend 2 & Week 3 & Weekend 3 & Week 4 \\
\hline Temperature $\left({ }^{\circ} \mathrm{C}\right)$ & $1.5 \pm 0.6$ & $0.1 \pm 1.0$ & $0.9 \pm 0.7$ & $7.7 \pm 1.1$ & $2.8 \pm 0.5$ & $3.4 \pm 1.4$ & $2.0 \pm 0.7$ \\
RH (\%) & $84 \pm 4$ & $91 \pm 2$ & $95 \pm 2$ & $91 \pm 4$ & $83 \pm 7$ & $83 \pm 7$ & $89 \pm 3$ \\
Wind velocity $\left(\mathrm{m} \mathrm{s}^{-1}\right)$ & $1.66 \pm 0.24$ & $1.42 \pm 0.4$ & $1.74 \pm 0.2$ & $2.5 \pm 0.95$ & $2.5 \pm 0.43$ & $4.36 \pm 1.08$ & $1.55 \pm 0.32$ \\
Main wind direction (frequency) & $150(58 \%)$ & $150(64 \%)$ & $140(75 \%)$ & $280(80 \%)$ & $280(90 \%)$ & $300(95 \%)$ & $300(40 \%)$ \\
\hline
\end{tabular}

sically followed the mean profiles of the nitrate and sulfate concentrations. The weather conditions in each week are presented in Table 2. While weeks 3 and 4 had similar weather conditions, week 2 was characterized by higher $\mathrm{RH}$ and a different wind direction (southeastern sector during $75 \%$ of the time). Changes in air mass character (more continental or more maritime) and larger wet depositions and precipitations could explain the differences between the diurnal profiles of week 2 and the two other weeks.

The comparison of the weekends' diurnal profiles shows similarities between weekend 1 and 2, even if the aerosol concentrations were not the same. These 2 weekends clearly differed from weekend 3 (Fig. 2). Weekends 1 and 2 were characterized by an increase of organics, sulfate and chloride concentrations during day time, reaching a maximum during the afternoon. Contrary to this, during weekend 3, all concentrations decreased during day, reaching a minimum after 16:00. As before, the weather conditions during these 3 weekends are compared in Table 2. The main difference between weekends 1 and 2 and weekend 3 is the wind velocity which was highest during weekend 3 . This suggests a better dilution of the emissions during daytime in weekend 3. In the evening, the concentrations might have increased due to the stratification of the atmosphere which could have limited the dilutions effect.

A comparison of week 3 and 4 with weekend 1 and 2 points out two different tendencies: while during weekdays, the organic aerosol presented two maxima, early in the morning and in the evening, during the weekends; the organic concentrations seemed to continuously increase during the morning, reaching a maxima in the mid-afternoon. However, hourly unpaired t-test analyses of the organic concentration demonstrated that the difference of these two tendencies was not statistically significant.

\subsection{Organic aerosol composition}

\subsubsection{Factor analysis}

\section{PMF analysis}

The analysis of the organic aerosol components was conducted with the unit mass resolution (UMR) organic mass spectra (from $\mathrm{m} / \mathrm{z}, 12$ to $\mathrm{m} / \mathrm{z}, 100$ ) and was performed using the
Positive Matrices Factorization method (PMF) developed by Paatero and Tapper (1994) and according to the PMF evaluation Tool (PET), a custom software for solution comparison and analysis, developed by Ulbrich et al. (2009). Prior to the analysis, the organic mass spectra matrix and its corresponding error matrix were determined and the error matrix was corrected for minimum error and low signal-to-noise ratio (see Ulbrich et al., 2009). The contribution of the $\mathrm{CO}_{2}^{+}$ ion to fragments $\mathrm{m} / \mathrm{z} 16,17,18$ and 44 were downweighted following the procedure described by Ulbrich et al. (2009). Then, PMF analysis was run using 1 to 5 factors. In a first step, the different factor solutions were evaluated using the $Q / Q_{\exp }$ ratio. The $Q$ value represents the number of the degrees of freedom of the system. A $Q / Q_{\text {exp }}$ larger than 1 indicates a possible underestimation of the error or the identify sources cannot fully described the variability of the measurements. On the other hand, a $Q / Q_{\exp }$ lower than 1 indicates a possible overestimation of the errors of the input (Paatero et al., 2002). The sensitivity to matrix rotation was explored by varying the fPeak from -1 to +1 with steps of 0.1 . The uncertainty of the solution (Seed) was investigated using 100 random starting points. Finally, the quantitative uncertainty of the identified factors was estimated by 100 bootstrapping runs.

The 2-factors solution separates Oxygenated Organic Aerosols (OOA) from a mixture of primary organic aerosol (POA) with high contributions of masses $\mathrm{m} / \mathrm{z} 55,57$ and $60\left(Q / Q_{\exp }=5.16\right)$. The 3-factors solution splits the POA into Hydrocarbon-like Organic Aerosol (HOA) and BiomassBurning Organic Aerosol (BBOA) $\left(Q / Q_{\exp }=4.35\right)$. The 4factors solution additionally splits the OOA $\left(Q / Q_{\exp }=3.59\right)$ and the 5 -factors solution results from further splitting of the OOA $\left(Q / Q_{\exp }=2.94\right)$.

The 3 -factors solution was retained after having investigated the fPeak and Seed influences on the resulting time series and mass spectra as well as the differences between the solutions in the mass spectra and time series. The final solution was obtained for a fPeak value of 0.0 which was used for Seed and bootstrap investigations. The $Q / Q_{\exp }$ and the factors obtained for different fPeak values were nearly identical. The retained solution was stable over the different starting points tested with relatively low uncertainties (Fig. S2). The factor identification was performed by comparing the time 
series and mass spectra of each factor with external tracers (nitrate, sulfate, potassium, chloride, $\mathrm{C}_{2} \mathrm{H}_{4} \mathrm{O}_{2}^{+}, \ldots$ ), available gas phase measurements $\left(\mathrm{NO}_{\mathrm{x}}\right.$ and $\left.\mathrm{CO}\right)$, off-line filter results, and reference source mass spectra available on the AMS MS database (http://cires.colorado.edu/jimenez-group/ AMSsd/index.html) (Ulbrich et al., 2009). Finally, the 3factors solution was preferred to the 4-factors solution principally due to the uncertainties regarding the identification of the second OOA factor in the 4-factors solution.

\section{Factors identification}

\section{Biomass burning organic aerosol}

The corresponding BBOA factor was identified by comparing its factor mass spectrum with that one published by Lanz et al. (2007) (Fig. S3). The identified BBOA factor is also characterized by a large contribution of the organic fragments $\mathrm{m} / \mathrm{z} 60$ and $\mathrm{m} / \mathrm{z} 73$ which are considered as tracers of biomass burning aerosols (e.g. Alfarra et al., 2007; Schneider et al., 2006). In the identified BBOA factor, the organic fragments $\mathrm{m} / \mathrm{z}, 60$ and $\mathrm{m} / \mathrm{z} .73$ represented $4.2 \%$ and $1.7 \%$ of the total BBOA mass spectra, respectively. The contribution of $\mathrm{m} / \mathrm{z}$ 60 is slightly higher than the reported values of $2-4 \%$ in Switzerland (Lanz et al., 2010). The fragment $m / z, 44$ represented $3.3 \%$ of the total BBOA mass spectra. Based on the relation between the contribution of $\mathrm{m} / z 44$ and the $\mathrm{O} / \mathrm{C}$ ratio reported by Aiken et al. (2008) and Sun et al. (2009), a $\mathrm{O} / \mathrm{C}$ ratio of 0.20 was obtained for the BBOA factor which is in agreement with previously reported values (Aiken et al., 2008; He et al., 2011).

During the measurement period, the fragment $\mathrm{C}_{2} \mathrm{H}_{4} \mathrm{O}_{2}^{+}$ represented $90 \%$ of the total $\mathrm{m} / \mathrm{z}, 60$ and not surprisingly, the time series of the BBOA factor were strongly correlated to the $\mathrm{C}_{2} \mathrm{H}_{4} \mathrm{O}_{2}^{+}$(Fig. 3 and Fig. $\mathrm{S} 4, r^{2}=0.77$ ) as well as the $m / z, 73$ fragment $\mathrm{C}_{3} \mathrm{H}_{5} \mathrm{O}_{2}^{+}$(Fig. $\mathrm{S} 4, r^{2}=0.93$ ). Moreover, Fig. $\mathrm{S} 4$ also shows periods with no correlation between $\mathrm{C}_{2} \mathrm{H}_{4} \mathrm{O}_{2}^{+}$and BBOA which might be interpreted as a contribution of an organic compound other than BBOA to $\mathrm{C}_{2} \mathrm{H}_{4} \mathrm{O}_{2}^{+}$. However, this was not the case for $\mathrm{C}_{3} \mathrm{H}_{5} \mathrm{O}_{2}^{+}$. Potassium which can be emitted by biomass burning and was used as an inorganic biomass burning tracer (e.g. in Lee et al., 2005; Hudson et al., 2004) also presented a similar profile to the BBOA (Fig. 3 and Fig. S4, $r^{2}=0.83$ ). Both comparisons using reference mass spectra and comparisons using tracers confirmed our identification.

Although the BBOA mass spectra showed similarities to mass spectra of pure levoglucosan, the comparison of BBOA concentration with the total concentration of MA measured on filters samples revealed that BBOA corresponds to the sum of MA (slope 1.14, $r^{2}=0.89$, Fig. 4) rather than to levoglucosan alone (slope $0.5, r^{2}=0.65$ ). Therefore, the identified BBOA factor can be considered as a good tracer for the total amount of MA.

\section{Hydrocarbon-like organic aerosol}

The identified HOA factor, commonly considered as corresponding to primary organic aerosols (fossil fuel combustion), had a mass spectrum similar to previously reported HOA factors (Lanz et al., 2007; Ulbrich et al., 2009) (Fig. S3). The HOA mass spectrum was also characterized by a large contribution of the fragment $\mathrm{m} / z 57$ (3.6\% of the total HOA signal). A O/C ratio of 0.15 was estimated from the contribution of $\mathrm{m} / \mathrm{z} 44$ to the HOA mass spectra which agrees with previously reported values in urban areas (Aiken et al., 2008; He et al., 2011; Huang et al., 2011), but is higher than the reported $\mathrm{O} / \mathrm{C}$ ratio of motor vehicle exhaust $(0.03-$ 0.04; Mohr et al., 2009).

Compared to previous studies, the HOA time series correlated better with $\mathrm{CO}\left(r^{2}=0.47\right.$, Fig. S4) than $\mathrm{NO}_{\mathrm{x}}\left(r^{2}=\right.$ 0.38, Fig. 3 and Fig. S4), as previously reported (Lanz et al., 2010; Ulbrich et al., 2009; Zhang et al., 2005a). Unfortunately, no parallel online measurements of black carbon were performed and the daily averaged HOA concentration did not correlate with daily $\mathrm{PM}_{1} \mathrm{EC}$. The absence of a linear relationship between HOA and $\mathrm{PM}_{1}$ EC could be explained by the low number of filter samples and the uncertainties in the EC measurements.

As previously mentioned, wood combustion for domestic heating is used in approximately $30 \%$ of the houses in Seiffen. Therefore, other heating energy sources like liquid fuel have also to be considered (Saxony EPA agency data, Löschau, 2007). Consequently, during the cold period, heating systems using wood combustion or liquid fuel for domestic heating are emitted simultaneously. Thereby, two possible sources of the HOA factor have to be considered: (a) vehicle exhaust and (b) emissions from domestic heating. Considering a limited car traffic at Seiffen (less than 2000 vehicles per day, Saxony EPA agency data, Löschau, 2007), traffic emission should have a limited contribution to the HOA. The correlation between HOA and BBOA $\left(r^{2}=0.62\right.$, Fig. S4) confirms the suggested contribution of the residential heating to the HOA. Moreover, a direct contribution of the biomass burning emissions to HOA cannot be completely excluded. For example, DeCarlo et al. (2010) reported a contribution of biomass burning to HOA of $49 \%$ over the region of Mexico, using a CO source apportionment model. Unfortunately, such information was not available and due to the limited gas phase measurements performed here, it is not possible to clearly attribute a quantitative contribution of biomass burning and liquid fuel combustion to the identified HOA factor. Nevertheless, it seems reasonable to assume that residential heating (independently of the energy) represents the largest contribution of HOA.

\section{Oxygenated organic aerosol}

The last factor had mass spectra similar to the mass spectra of oxygenated organic aerosol (OOA) reported by Zhang 

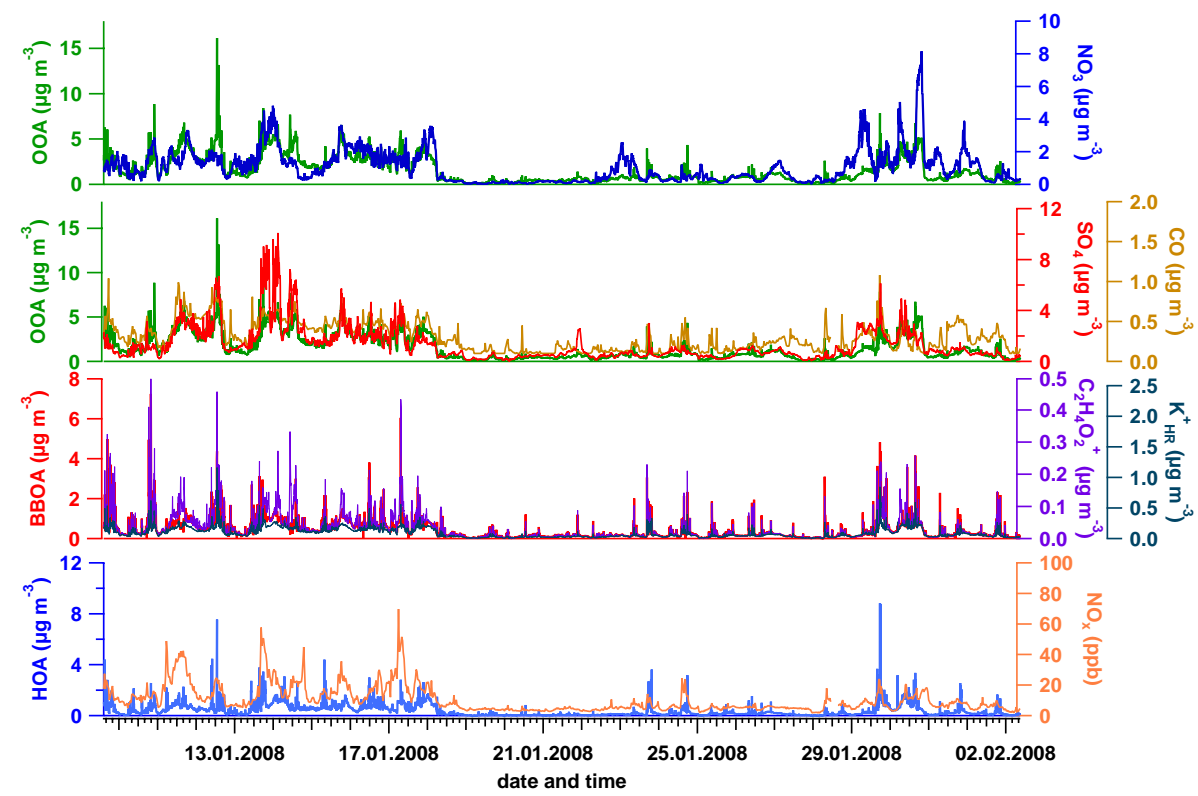

Fig. 3. Time series of the 3 factors and their selected tracer species (AMS time resolution 5 min, gas tracers time resolution 30 min).

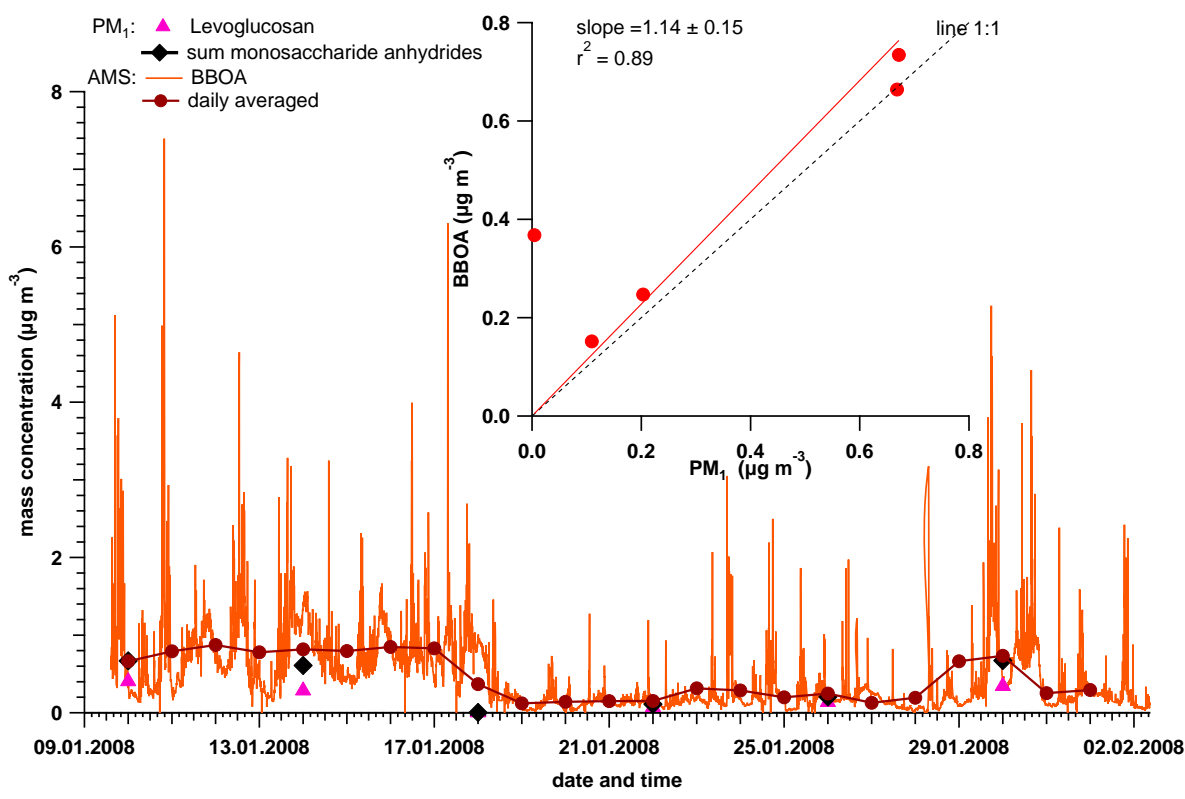

Fig. 4. Time series of BBOA factor and comparison with the sum of $\mathrm{PM}_{1} \mathrm{MA}$ identified (levoglucosan, arabitol, mannosan, mannitol, mannose, galactosan, glucose and sucrose).

et al. (2005b) (Fig. S3) and to the reference mass spectra of fulvic acid (Fig. S3) which is considered to be a model substance for Humic Like Substances (HULIS). The mass spectra of the OOA factor was characterized by a larger contribution of the fragments $\mathrm{m} / \mathrm{z}, 44(19 \%)$ and $\mathrm{m} / \mathrm{z}, 43(11 \%)$ which is in agreement with the previously reported values (e.g. Lanz et al., 2010). As done previously, the $\mathrm{O} / \mathrm{C}$ ratio (0.8) was estimated according to the contribution of the mass $\mathrm{m} / \mathrm{z}, 44$ which is in agreement with previous measurements (Aiken et al., 2008; He et al., 2011; Ng et al., 2010) as well as with the presence of more oxygenated organic compounds in this factor compared to BBOA and HOA.

The time series of the OOA factor correlated better with $\mathrm{SO}_{4}\left(r^{2}=0.68\right.$, Fig. S5) than with $\mathrm{NO}_{3}\left(r^{2}=0.50\right.$, Fig. S5). Based on the literature (Lanz et al., 2010; Ulbrich et al., 2009; Zhang et al., 2005a) this might be explained by long 


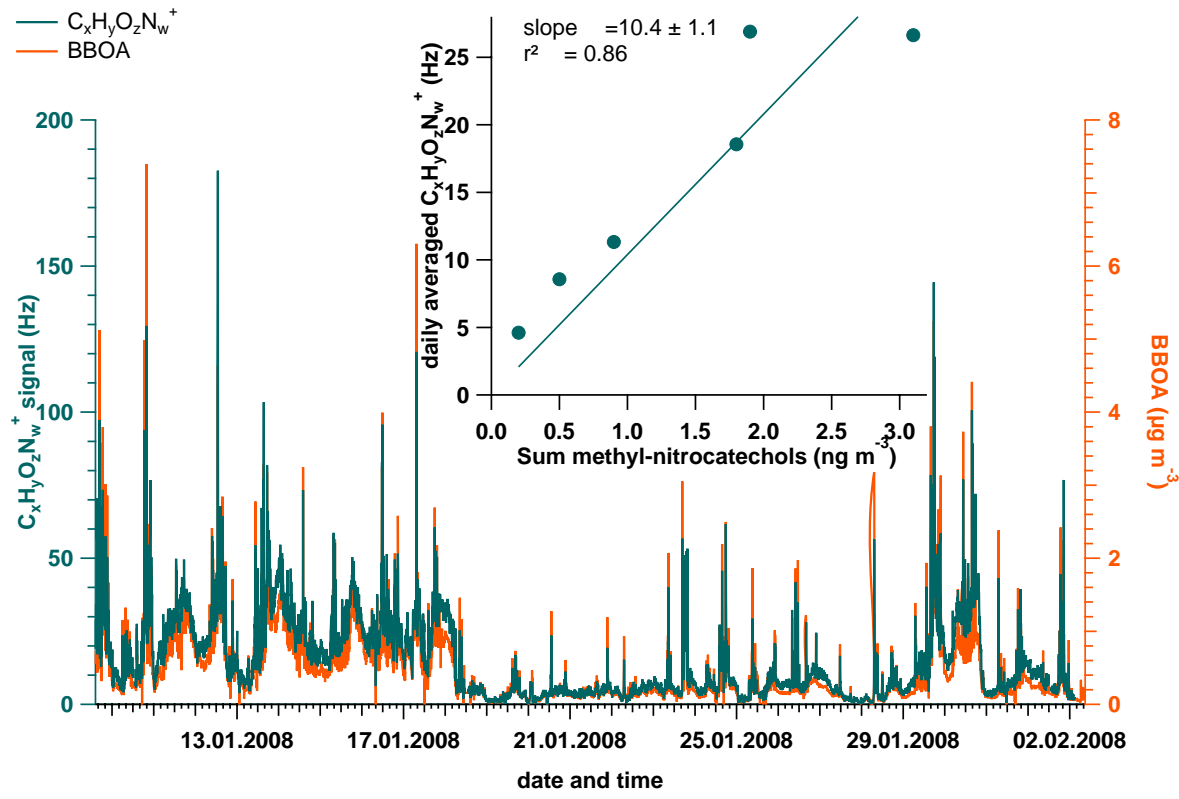

Fig. 5. Comparison of the $\mathrm{C}_{\mathrm{x}} \mathrm{H}_{\mathrm{y}} \mathrm{O}_{\mathrm{z}} \mathrm{N}_{\mathrm{w}}^{+}$fragments with BBOA factor and daily $\mathrm{PM}_{1}$ methy-nitrocatechols.

range transport or regional aerosols. Nevertheless, the OOA factor also correlated with $\mathrm{CO}\left(r^{2}=0.61\right.$, Fig. S5) which suggests a possible combustion origin. The emission of high molecular weight compounds during biomass burning was previously reported by several authors (e.g. Hoffer et al., 2006; Mukai and Ambe, 1986; Mayol-Bracero et al., 2002; Lin et al., 2010; Weimer et al., 2008). During their laboratory investigations, Weimer et al. (2008) observed a strong similarity between the organic mass spectra of wood burning emissions and the fulvic acid mass spectra, especially during the smoldering phase. Consequently, taking into account the sampling site environment leads to the assumption that at least a part of the OOA factor should have a direct wood combustion origin. However, relying on the available parallel measurements only, a quantified distinction between the long range transport OOA and the wood combustion related OOA was not possible.

Moreover, a part of the OOA might also be linked to the aging of the wood combustion emissions which leads to the formation of less volatile organics aerosols, for example due to photo-oxidation processes during day time (Capes et al., 2008; Grieshop et al., 2009a, b). In addition, taking into account the high relative humidity during measurement period and regarding laboratory and simulation studies of the levoglucosan oxidation by $\mathrm{OH}$-radical made by Hennigan et al. (2010) and Hoffmann et al. (2010), the aging of BBOA on deliquescence particles can be expected. The presence of SOA coming from the OH-oxidation of wood combustion VOCs during measurement periods was demonstrated by Iinuma et al. (2010). Indeed, using the $\mathrm{PM}_{1}$ filter measurements made during the entire project (i.e. from October 2007 to March 2008) and additional laboratory measurements in the simulation chamber, Iinuma et al. (2010) correlated the presence of methyl-nitrocatechols with the photooxidation of $m$-cresol directly emitted by wood combustion. In our study, the high resolution analysis of the AMS mass spectra showed a similar profile between the $\mathrm{C}_{\mathrm{x}} \mathrm{H}_{\mathrm{y}} \mathrm{O}_{\mathrm{z}} \mathrm{N}_{\mathrm{w}}^{+}$fragments (with $z$ higher than 1) and the previously indentified BBOA factor, besides a good correlation with identified methyl-nitrocatechols (Fig. 5). This is in agreement with the observation made by Iinuma et al. (2010). It is therefore reasonable to conclude that during our measurements, the $\mathrm{C}_{\mathrm{x}} \mathrm{H}_{\mathrm{y}} \mathrm{O}_{\mathrm{z}} \mathrm{N}_{\mathrm{w}}^{+}$fragments were related to methyl-nitrocatechol issues of the oxidation of $m$-cresol. This might also be considered as a possible source of the observed OOA factor.

The distinction between the different sources of OAA appears to be challenging in our conditions. It was not possible to clearly distinguish the wood burning contribution from the long range transport. Hence, the OOA factor represented a mixture of these two main sources. The mean contributions of OOA, BBOA and HOA to total organics were approximately $62 \%, 20 \%$ and $17 \%$, respectively. The contributions of BBOA and HOA are in the range of values observed by Lanz et al. (2010) in several places in the Alpine mountains (17-49\% and 6-16\% of OA for BBOA and HOA, respectively), but slightly lower than the values previously observed by Favez et al. (2010) $(\mathrm{BBOA}=37 \%)$.

\subsubsection{Diurnal profiles of the organic aerosol}

The diurnal profiles of the main organic components (OOA, BBOA and HOA) are shown in Fig. 6. As previously 

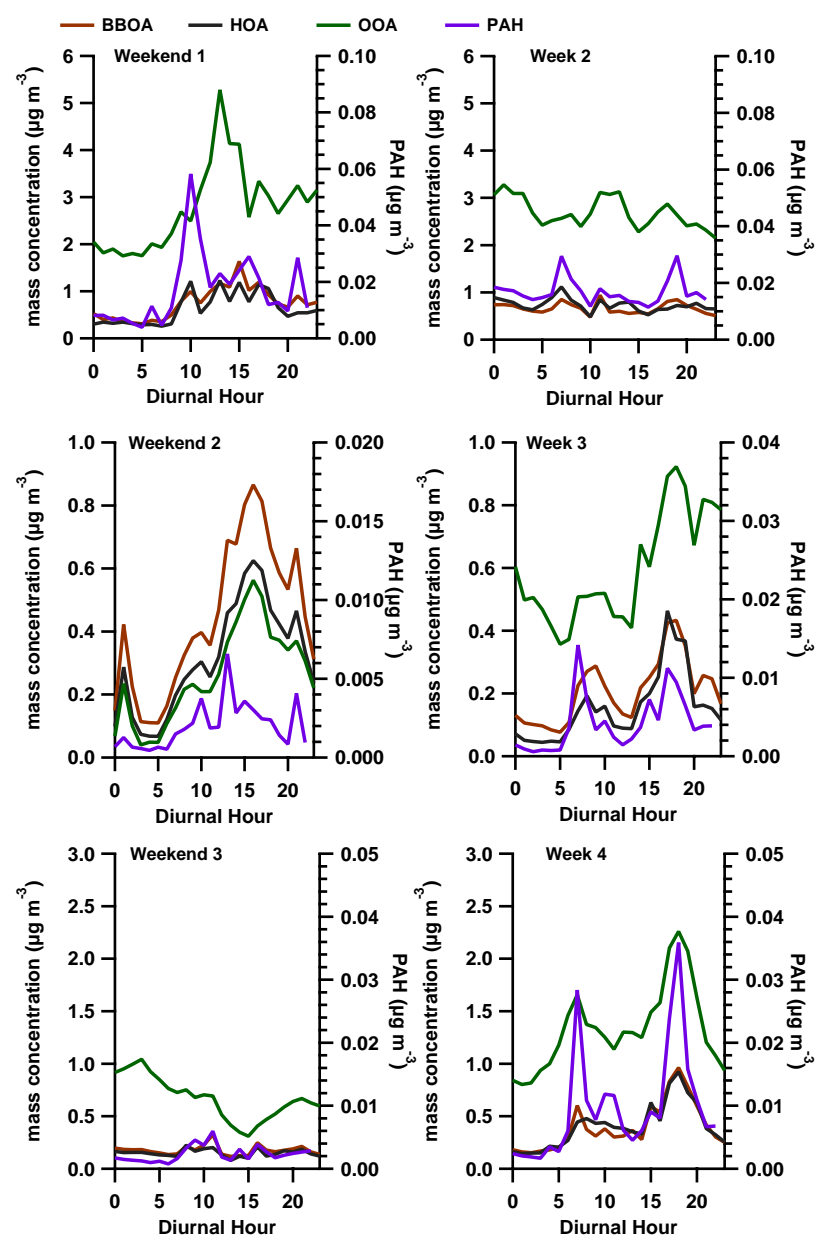

Fig. 6. Diurnal variations of the organic factors (BBOA, HOA and OOA) and PAH concentrations during weekends (left) and weeks (right). Week and weekend number referred to time periods described in Fig. 1.

described for the main aerosol components, the diurnal profiles were divided in 3 weekdays and 3 weekends (Fig. 1) and similar conclusions could be drawn by comparing the different weeks and weekends patterns. The diurnal profile of week 2 differed from the profiles of weeks 3 and 4 . While no clear diurnal variations of each OA factor was observed during week 2 , even if it corresponded to the highest concentrations, a clear variation of BBOA, HOA and OOA could be observed during weeks 3 and 4. During these two weeks, tracers of fresh/primary organic aerosol (POA) emissions (i.e. BBOA and HOA) showed two maxima: a first around 08:00 and a second around 19:00. Their concentrations were slightly lower during day which may be attributed to a possible diminution of the emission as well as to a dilution effect by an increase of the mixed layer height. The evening peaks of BBOA and HOA were higher than the morning peaks, as previously observed by Lanz et al. (2010) and Sandradewi et al. (2008). Although this suggests larger emissions in the evening, the concentrations could also be enhanced by local meteorological conditions like a lower mixed layer height limiting the dilution process during the night. Interestingly, the OOA factor presented a profile similar to that of POA during week 4 which was less pronounced during week 3 and therefore confirms residential heating as a possible source of OOA.

During weekends 1 and 2, an increase of BBOA and HOA concentrations during day time could be observed, reaching a maximum in mid-afternoon and then slowly decreasing to a minimum during the night with a small peak at 22:00. During these two weekends, the OOA concentrations followed a tendency similar to that of BBOA and HOA. Not surprisingly, these concentrations decreased during the day of weekend 3 , as previously described for the total organics. As for total OA, comparisons of the hourly BBOA and HOA concentrations between weeks 3 and 4 as well as between weekends 1 and 2 were performed using unpaired t-test analyses. The differences of concentrations were not statistically significant.

Although different tendencies could be observed between weekdays and weekends, these differences were small in term of concentration. This may result from the limiting sampling time as well as the fact that emissions from the local artisanal activity during weekdays were basically replaced by residential emissions during weekends, as suggested by the time switch observed between weekdays and weekends. The fact that HOA and BBOA had similar profiles confirms that $\mathrm{HOA}$ is correlated with residential heating rather than car exhaust. This is in agreement with the low car traffic mentioned above. Therefore, our results suggest that residential heating (BBOA and HOA) represented at least $37 \%$ of the total OA at Seiffen during our measurement period.

\subsubsection{Polycyclic aromatic hydrocarbons}

Wood combustion is known to be a source of Polycyclic aromatic hydrocarbon $(\mathrm{PAH})$ produced by the pyrolysis of cellulose and lignin (e.g. Rogge et al., 1998; Dhammapala et al., 2007; Mandalakis et al., 2005; Kozinski and Saade, 1998). PAH were identified on the AMS organic mass spectra, according to the fragmentation table described by Dzepina et al. (2007). The PAH time series is presented in Fig. 7. A mean value of $10 \pm 22 \mathrm{ng} \mathrm{m}^{-3}$ was obtained for the whole campaign. Although the AMS is not able to provide PAH speciation as filter analyses made by CPP-GC-MS, a comparison of the AMS PAH concentrations with the sum of the 18 PAH identified by filter samples showed a strong correlation (slope $=0.77, r^{2}=0.97$; Fig. 7 insert panel). Taking into account the uncertainties of 35-38\% when identifying the PAH by AMS (Dzepina et al., 2007) and the limited number of filter samples, we conclude that the measured AMS PAH concentration represents a good assumption of the total particulate PAH content. The mean PAH mass concentrations measured by both methods (10 $\mathrm{ng} \mathrm{m}^{-3}$ for AMS PAH and $12 \mathrm{ng} \mathrm{m}^{-3}$ for filters, respectively) are in good agreement 


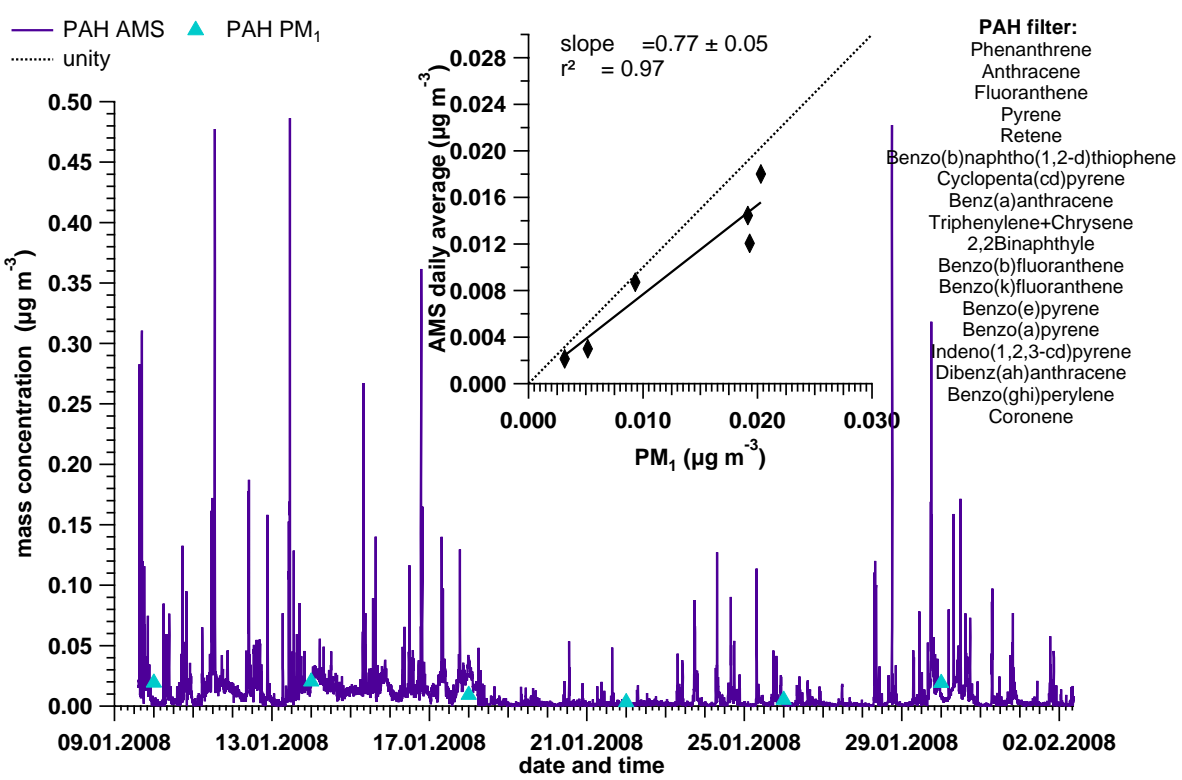

Fig. 7. AMS-PAH time series and comparison with daily $\mathrm{PM}_{1}$ filters.

with residential wood combustion PAH concentrations previously reported for similar locations $\left(10.2 \mathrm{ng} \mathrm{m}^{-3}\right.$ (Glasius et al., 2008); 30 to $22.9 \mathrm{ng} \mathrm{m}^{-3}$, Bari et al., 2010a; Bari et al., 2009) and with the mean PAH concentration observed by Marchand et al. (2004) in urban and near-city background sites in French alpine valleys (range $2.3-22.8 \mathrm{ng} \mathrm{m}^{-3}$ ). However, it is two times higher than the mean concentration found by Favez et al. (2010) in the city of Grenoble (France). PAH contributed $0.5 \pm 0.01 \%$ to total organic aerosol which is slightly higher than the values reported for Switzerland (0.1\%, Lanz et al., 2010).

In addition, the PAH time series (Fig. 7) shows several short-term events (lasting approximately $20-45 \mathrm{~min}$ ) with concentrations up to $500 \mathrm{ng} \mathrm{m}^{-3}$ which are extremely high compared to the mean concentration of $10 \mathrm{ng} \mathrm{m}^{-3}$. Marchand et al. (2004) reported such high concentrations of PAH (up to $150 \mathrm{ng} \mathrm{m}^{-3}$ ) using $12 \mathrm{~h}$ sampling in two French alpine valleys during anticyclonic conditions with low temperature. However, the short-term of these events of high PAH concentrations were observed during the whole campaign and their frequencies did not seem to be directly related to the meteorological conditions. Considering their durations, these high PAH events might be caused by measuring direct sources of PAH emissions, e.g. a plume of a chimney exhaust of adjacent houses that due to a small change in wind direction moved to our sampling line. Unfortunately, as the wind direction was measured below the roof level, with a time resolution of $30 \mathrm{~min}$ only (see Sect. 2.2), it was not possible to attribute these peaks to a precise house/source. Nevertheless, due to their longer sampling time, filter samplers cannot show these peaks. This highlights the importance of a time resolution higher than 12 or $24 \mathrm{~h}$ in order to identify strong sources of PAH.
As done previously for the different NR-PM 1 and organic components, diurnal variations of PAH concentrations in the different weeks and weekends were compared (Fig. 6). The difference between weeks is less pronounced than previously reported for HOA and BBOA. A morning and evening peaks were observed during all 3 weeks, being less pronounced during week 2. During night, the PAH concentration decreased near to zero except for week 2. In agreement with the larger influence of the long range transport of pollutants during this period, this suggests a higher background concentration.

The PAH concentrations were highest during weekend 1. As in week 2, this certainly correlated with the influence of more polluted air masses. Similarly to the week comparison, the different PAH diurnal profiles of all weekends showed some similarities: the PAH concentrations started to increase later than during weekdays, reached a maximum before noon and decreased in the afternoon. Like for BBOA and HOA, the PAH concentrations also reached a peak at around 22:00, confirming the link between PAH and residential heating. In opposition to the statistical analyses performed before with BBOA and HOA, the difference of PAH concentrations at 07:00, 10:00, 12:00, 13:00 and 16:00 were statistically significant between weekends 1-2 and weeks 3-4.

Taking together, the BBOA, HOA and PAH diurnal profiles do not suggest pronounced differences in terms of emissions between weekdays and weekends. However, the significant differences found between the PAH concentrations during weekdays vs. weekends suggest differences in the burning conditions. As wood combustion emissions strongly depend on the burning conditions (Johansson et al., 2004), this difference in PAH concentration and not in HOA and $\mathrm{BBOA}$ might be interpreted as resulting from the difference 
in aerosol composition emitted from residential heating systems and bigger heating systems used by the artisanal factories. Nevertheless, further measurements are necessary to confirm this hypothesis.

\subsubsection{Contributions of the residential wood combustion to total PAH}

As previously mentioned, the main interest of this field campaign was to quantify the impact of residential wood combustion on the local air quality in Seiffen. Using the high time resolution of the BBOA, HOA and PAH concentrations, the contribution of wood combustion to total PAH concentration was estimated. In order to do so, the ratio PAH/BBOA was calculated (Fig. 8 upper panel). Depending on the nature of the wood fuel as well as on the burning conditions, different values of the emission ratio PAH/levoglucosan or PAH/MA were reported (e.g. PAH/MA ranging from 0.0007 to 0.014 (Iinuma et al., 2007) and from 0.06 to 0.113 (Dhammapala et al., 2007)). According to this and regarding the slope of 0.03 $\left(r^{2}=0.80\right)$ between total PAH and total MA obtained during the measurement period from the filters, a setting value of $\mathrm{PAH} / \mathrm{BBOA}=0.03$ was considered to separate $\mathrm{PAH}$ directly related to wood combustion emissions (ratio $<0.03$; referred to $\mathrm{PAH}_{\mathrm{wb}}$ here) from $\mathrm{PAH}$ not correlated to BBOA, but coming from other PAH sources like car exhaust and/or domestic liquid fuel heaters (ratio $>0.03$; referred to $\mathrm{PAH}_{\text {no-wb }}$ here). Therefore, the $\mathrm{PAH}_{\mathrm{no}-\mathrm{wb}}$ could be connected to the HOA factor. As presented in the bottom panel of Fig. 8, $\mathrm{PAH}_{\mathrm{wb}}$ (in purple) is related linearly to BBOA (slope = $\left.0.015, r^{2}=0.87\right)$, indicating that $\mathrm{PAH}_{\mathrm{wb}}$ emissions represent about $1.5 \%$ of the emitted mass of BBOA (e.g. total MA compounds). This is in agreement with the range of 0.7 to $2.2 \%$ defined by Weimer et al. (2008) who measured the emissions from different wood species during flaming and smoldering modes in the laboratory.

According to this, the $\mathrm{PAH}_{\mathrm{wb}}$ concentration was estimated from the BBOA time series and compared to the total PAH concentration. Consequently, during the AMS measurement period in Seiffen, $\mathrm{PAH}_{\mathrm{wb}}$ was assumed to contribute about $62 \%$ to the total particulate PAH mass concentration. This result confirms the impact of residential wood combustion on the local PAH concentration reported by Boström et al. (2002), Mandalakis et al. (2005) and Sheesley et al. (2009) in Sweden $\left(\mathrm{PAH}_{\mathrm{wb}}=50-80 \%\right)$. However, Mandalakis et al. (2005) who compared the contribution of $\mathrm{PAH}_{\mathrm{wb}}$ in three different European background sites (Sweden, Croatia and Greece) reported large variations of the $\mathrm{PAH}_{\mathrm{wb}}$ fractions (e.g. only $10 \%$ in southern European atmosphere) and justified this finding by differences in the contribution of residential wood combustion to total house heating systems.

Moreover, residential wood combustion seems to be the main source of individual PAH. Sheesley et al. (2009) estimated that in Lycksele (Sweden), 71-87\% of individual PAH may have a wood combustion origin and Nielsen and

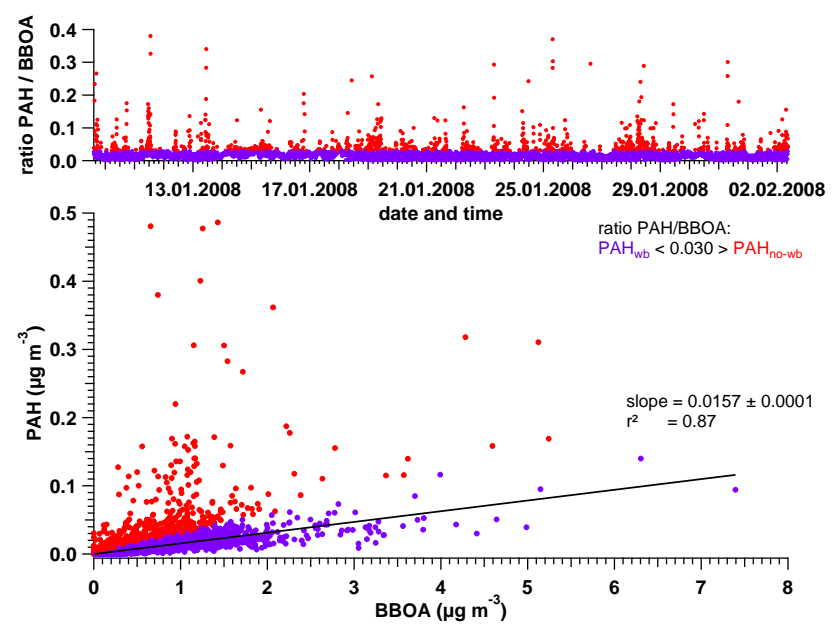

Fig. 8. Estimation of the biomass burning contribution to total PAH concentration. The upper panel represents the time series of the ratio PAH/BBOA and the bottom panel shows the correlation between $\mathrm{PAH}$ and BBOA. Colors correspond to the differentiation between PAH correlated to wood combustion (purple) and not correlated to wood combustion (red).

Illerup (2006) argued that in some locations in Denmark, 80 to $90 \%$ of some individual PAH compounds like $\mathrm{B}[\mathrm{a}] \mathrm{P}$ were caused by wood combustion. These results are in accordance with our assumption that $\mathrm{PAH}_{\mathrm{wb}}$ contribution represents a main source of PAH in Seiffen (ranging from 2 to $100 \%$ of total PAH). Moreover, Bari et al. (2010a) reported a contribution of $44 \%$ of the potential carcinogenic PAHs to total particulate PAH pointing out the potential impact on human health. It is important to link these results to the actual European legislation and more specially to the European Directory $2004 / 107 / C E$, imposing to all European Member States from the 31 December 2012 a value of $1 \mathrm{ng} \mathrm{m}^{-3}$ for the total content of $B[a] P$ in the $\mathrm{PM}_{10}$ fraction averaged over a calendar year. The $B[a] P$ was chosen because of its toxicity and because it is considered to be a good indicator of the total PAH content in the air. According to our results and previous discussion, we conclude that an annual value might be representative for the total PAH concentration, but not useful enough to estimate the real human exposition to PAH and seasonal variations.

Finally, based on the high time resolution of the AMS, our results outline the need to carefully monitor PAHs in the particles as well as in the gas phase to provide a better understanding of human exposure. For this kind of approach, parallel AMS and filters sample measurements represent a promising method to provide high time resolution total PAH concentration and a clear fingerprint of the PAH composition. 


\section{Conclusions}

In order to study the impact of residential wood combustion on local PM in the small town of Seiffen (Saxony, Germany), an AMS was deployed during January 2008, completing a longer period of daily $\mathrm{PM}_{1}$ filter measurements. While filter samples provided a daily detailed chemical composition of PAH and anhydrous monosaccharide compounds, the AMS provided a highly time resolved (5 min) information about the daily variation of the NR-PM . Using PMF analysis, the AMS organic signal was decomposed in 3 factors - OOA, BBOA and HOA - corresponding to $62 \%, 20 \%$ and $17 \%$ of the total OA, respectively. In addition, the PAH concentration (mean concentration of $10 \mathrm{ng} \mathrm{m}^{-3}$ ) extracted from the organic mass spectra (Dzepina et al., 2007) represented $0.5 \%$ of total OA. The presence of short-term events of extremely high PAH concentrations were directly attributed to a plume of chimney exhaust emitted from houses located close to the sampling place. BBOA factor and AMS PAH were successfully compared to daily $\mathrm{PM}_{1}$ filter samples, leading to the conclusion that they are good estimates of the total particle content in MA and PAH, respectively. Moreover, according to its similarity with fulvic acid mass spectrum (a model substance for HULIS) and its correlation with the CO time series, a possible contribution of wood combustion to OOA was suggested. Considering the low car traffic of the village and its correlation with BBOA and CO, HOA was also found to be mainly linked to residential heating. Although wood combustion was performed in only one-third of the houses in Seiffen, it represents the main primary source of particles. We thus conclude that POA emissions at Seiffen mainly corresponded to general residential heating during the measurement period. Because of the high time resolution of the AMS measurements, it was possible to observe diurnal profiles of the identified aerosol components. A strong influence of the weather conditions on the diurnal profiles and aerosol concentration was observed. Nevertheless, comparing weeks and weekends with closed meteorological conditions, two distinct trends could be observed between weekdays (with maxima of POA early in the morning and in the evening) and weekends (maximum of POA during the afternoon). The differences in BBOA, HOA and PAH concentrations between weekdays and weekends were only significantly different for $\mathrm{PAH}$, suggesting a possible influence of the burning conditions and particle compositions rather than emission intensity. PAH emitted by residential wood combustion was estimated at about $1.5 \%$ of the total mass of BBOA, representing approximately $62 \%$ of the total PAH measured. The large contribution of the residential wood combustion to the PAH concentration highlights its possible impact on human health, as considered in previous toxicological studies. It also emphasizes the need to decrease the particulate emission of residential wood combustion in order to decrease the atmospheric PAH concentrations, as requested by the European Directory 2004/107/CE.
Our measurements draw attention to the advantages of a combination of on-line (AMS) and off-line (filter samples) measurements. While the AMS provides information about changes in the concentration, filter samplers provide the chemical finger print of the particles during the whole day. The filter samples can for example, segregate between softwood and hardwood combustion (Bari et al., 2009, 2010b; Schauer and Cass, 2000). Combining off-line and on-line measurements represents a method to understand the changes of the aerosol chemical composition as well as the human exposure to toxic chemical compounds as polycyclic aromatic hydrocarbons. Due to the limiting time measurements (4 weeks), our results cannot be considered as representative for all winter conditions. Longer campaigns including online and daily filter sampling taking every day to increase the number of samples are needed for better statistical analyses.

Although residential wood combustion emissions strongly depend on burning conditions, type of wood (e.g. Johansson et al., 2004), and/or local meteorological conditions, the promotion of this source of energy by the local policy also contribute to increase the impact of residential wood burning on local air quality. In the current context of a large development of residential wood combustion and governmental wishes to improve local air quality, our results confirm the requirement of highly controlled domestic heating emissions including wood combustion in addition to the actual regulations mainly focusing on the reduction of industrial and traffic emissions.

\section{Supplementary material related to this article is available online at: http://www.atmos-chem-phys.net/11/12697/2011/ acp-11-12697-2011-supplement.pdf.}

Acknowledgements. This works was supported by the Sächsisches Lamdesamt für Umwelt und Geologie (LfULG), Dresden (Germany) grant number 13-0345.42/275.

Edited by: T. Kirchstetter

\section{References}

Aiken, A. C., DeCarlo, P. F., and Jimenez, J. L.: Elemental analysis of organic species with electron ionization highresolution mass spectrometry, Anal. Chem., 79, 8350-8358, doi:10.1021/ac071150w, 2007.

Aiken, A. C., Decarlo, P. F., Kroll, J. H., Worsnop, D. R., Huffman, J. A., Docherty, K. S., Ulbrich, I. M., Mohr, C., Kimmel, J. R., Sueper, D., Sun, Y., Zhang, Q., Trimborn, A., Northway, M., Ziemann, P. J., Canagaratna, M. R., Onasch, T. B., Alfarra, M. R., Prevot, A. S. H., Dommen, J., Duplissy, J., Metzger, A., Baltensperger, U., and Jimenez, J. L.: O/C and OM/OC ratios of primary, secondary, and ambient organic aerosols with highresolution time-of-flight aerosol mass spectrometry, Environ. Sci. Technol., 42, 4478-4485, doi:10.1021/es703009q, 2008. 
Alfarra, M. R., Prevot, A. S. H., Szidat, S., Sandradewi, J., Weimer, S., Lanz, V. A., Schreiber, D., Mohr, M., and Baltensperger, U.: Identification of the mass spectral signature of organic aerosols from wood burning emissions, Environ. Sci. Technol., 41, 57705777, doi:10.1021/Es062289b, 2007.

Allan, J., Delia, A. E., Coe, H., Bower, K. N., Alfarra, R. M., Jimenez, J. L., Middlebrook, A. M., Drewnick, F., Onasch, T. B., Canagaratna, M. R., Jayne, J. T., and Worsnop, D. R.: A generalised method for the extraction of chemically resolved mass spectra from Aerodyne aerosol mass spectrometer data, J. Aerosol Sci., 35, 909-922, doi:10.1016/j.jaerosci.2004.02.007, 2004.

Bari, M. A., Baumbach, G., Kuch, B., and Scheffknecht, G.: Wood smoke as a source of particle-phase organic compounds in residential areas, Atmos. Environ., 43, 4722-4732, doi:10.1016/j.atmosenv.2008.09.006, 2009.

Bari, M. A., Baumbach, G., Brodbeck, J., Struschka, M., Kuch, B., Dreher, W., and Scheffknecht, G.: Characterisation of particulates and carcinogenic polycyclic aromatic hydrocarbons in wintertime wood-fired heating in residential areas, Atmos. Environ., 44, 3823-3832, doi:10.1016/j.atmosenv.2010.06.031, 2010a.

Bari, M. A., Baumbach, G., Kuch, B., and Scheffknecht, G.: Temporal variation and impact of wood smoke pollution on a residential area in southern Germany, Atmos. Environ., 44, 3823-3832, doi:10.1016/j.atmosenv.2010.06.031, 2010b.

Bolling, A. K., Pagels, J., Yttri, K. E., Barregard, L., Sallsten, G., Schwarze, P. E., and Boman, C.: Health effects of residential wood smoke particles: the importance of combustion conditions and physicochemical particle properties, Particle and Fibre Toxicology, 6, 29, 20 pp., doi:10.1186/1743-8977-6-29, 2009.

Boström, C. E., Gerde, P., Hanberg, A., Jernström, B., Johansson, C., Kyrklund, T., Rannug, A., Törnqvist, M., Victorin, K., and Westerholm, R.: Cancer risk assessment, indicators, and guidelines for polycyclic aromatic hydrocarbons in the ambient air, Environ. Health Perspect., 110, 451-488, 2002.

Brüggemann, E. and Rolle, W.: Changes of some components of precipitation in East Germany after the reunification, Water Air Soil Poll., 107, 1-23, 1998.

Canagaratna, M. R., Jayne, J. T., Jimenez, J. L., Allan, J. D., Alfarra, M. R., Zhang, Q., Onasch, T. B., Drewnick, F., Coe, H., Middlebrook, A., Delia, A., Williams, L. R., Trimborn, A. M., Northway, M. J., Decarlo, P. F., Kolb, C. E., Davidovits, P., and Worsnop, D. R.: Chemical and microphysical characterization of ambient aerosols with the Aerodyne aerosol mass spectrometer, Mass Spectrom. Rev., 26, 185-222, doi:10.1002/mas.20115, 2007.

Capes, G., Johnson, B., McFiggans, G., Williams, P. I., Haywood, J., and Coe, H.: Aging of biomass burning aerosols over West Africa: Aircraft measurements of chemical composition, microphysical properties, and emission ratios, J. Geophys. Res.Atmos., 113, D00C15, doi:10.1029/2008jd009845, 2008.

DeCarlo, P. F., Kimmel, J. R., Trimborn, A., Northway, M. J., Jayne, J. T., Aiken, A. C., Gonin, M., Fuhrer, K., Horvath, T., Docherty, K. S., Worsnop, D. R., and Jimenez, J. L.: Field-deployable, high-resolution, time-of-flight aerosol mass spectrometer, Anal. Chem., 78, 8281-8289, doi:10.1021/ac061249n, 2006.

DeCarlo, P. F., Ulbrich, I. M., Crounse, J., de Foy, B., Dunlea, E. J., Aiken, A. C., Knapp, D., Weinheimer, A. J., Campos, T., Wennberg, P. O., and Jimenez, J. L.: Investigation of the sources and processing of organic aerosol over the Central Mexican Plateau from aircraft measurements during MILAGRO, Atmos. Chem. Phys., 10, 5257-5280, doi:10.5194/acp-10-52572010, 2010.

Dhammapala, R., Claiborn, C., Jimenez, J., Corkill, J., Gullett, B., Simpson, C., and Paulsen, M.: Emission factors of PAHs, methoxyphenols, levoglucosan, elemental carbon and organic carbon from simulated wheat and Kentucky bluegrass stubble burns, Atmos. Environ., 41, 2660-2669, doi:10.1016/j.atmosenv.2006.11.023, 2007.

Duplissy, J., Gysel, M., Sjogren, S., Meyer, N., Good, N., Kammermann, L., Michaud, V., Weigel, R., Martins dos Santos, S., Gruening, C., Villani, P., Laj, P., Sellegri, K., Metzger, A., McFiggans, G. B., Wehrle, G., Richter, R., Dommen, J., Ristovski, Z., Baltensperger, U., and Weingartner, E.: Intercomparison study of six HTDMAs: results and recommendations, Atmos. Meas. Tech., 2, 363-378, doi:10.5194/amt-2-363-2009, 2009.

Dzepina, K., Arey, J., Marr, L. C., Worsnop, D. R., Salcedo, D., Zhang, Q., Onasch, T. B., Molina, L. T., Molina, M. J., and Jimenez, J. L.: Detection of particle-phase polycyclic aromatic hydrocarbons in Mexico City using an aerosol mass spectrometer, Int. J. Mass. Spectrom., 263, 152-170, doi:10.1016/j.ijms.2007.01.010, 2007.

Engling, G., Carrico, C. M., Kreldenweis, S. M., Collett, J. L., Day, D. E., Malm, W. C., Lincoln, E., Hao, W. M., Iinuma, Y., and Herrmann, H.: Determination of levoglucosan in biomass combustion aerosol by high-performance anion-exchange chromatography with pulsed amperometric detection, Atmos. Environ., 40, S299-S311, doi:10.1016/j.atmosenv.2005.12.069, 2006.

EU: Combating climate change: The EU leads the way, EU report, available at: http://ec.europa.eu/publications/booklets/move/70/ en.pdf, 2007.

Favez, O., El Haddad, I., Piot, C., Boréave, A., Abidi, E., Marchand, N., Jaffrezo, J.-L., Besombes, J.-L., Personnaz, M.-B., Sciare, J., Wortham, H., George, C., and D'Anna, B.: Inter-comparison of source apportionment models for the estimation of wood burning aerosols during wintertime in an Alpine city (Grenoble, France), Atmos. Chem. Phys., 10, 5295-5314, doi:10.5194/acp-10-52952010, 2010.

Glasius, M., Ketzel, M., Wahlin, P., Bossi, R., Stubkjaer, J., Hertel, O., and Palmgren, F.: Characterization of particles from residential wood combustion and modelling of spatial variation in a low-strength emission area, Atmos. Environ., 42, 8686-8697, doi:10.1016/j.atmosenv.2008.04.037, 2008.

Gnauk, T., Muller, K., van Pinxteren, D., He, L. Y., Niu, Y. W., Hu, M., and Herrmann, H.: Size-segregated particulate chemical composition in Xinken, Pearl River Delta, China: OC/EC and organic compounds, Atmos. Environ., 42, 62966309, doi:10.1016/j.atmosenv.2008.05.001, 2008.

Grieshop, A. P., Donahue, N. M., and Robinson, A. L.: Laboratory investigation of photochemical oxidation of organic aerosol from wood fires 2: analysis of aerosol mass spectrometer data, Atmos. Chem. Phys., 9, 2227-2240, doi:10.5194/acp-9-2227-2009, 2009a.

Grieshop, A. P., Logue, J. M., Donahue, N. M., and Robinson, A. L.: Laboratory investigation of photochemical oxidation of organic aerosol from wood fires 1: measurement and simulation of organic aerosol evolution, Atmos. Chem. Phys., 9, 1263-1277, 
doi:10.5194/acp-9-1263-2009, 2009 b.

Gurjar, B. R., Jain, A., Sharma, A., Agarwal, A., Gupta, A., Nagpure, A. S., and Lelieveld, J.: Human health risks in megacities due to air pollution, Atmos. Environ., 44, 4606-4613, doi:10.1016/j.atmosenv.2010.08.011, 2010.

Hausmann, A.: Holzkleinfeuerungsanlagen in Sachsen, Sächsisches Landesamt für Umwelt, Landwirtschaft und Geologie, Heft 17/2010, 2010.

He, L. Y., Huang, X. F., Xue, L., Hu, M., Lin, Y., Zheng, J., Zhang, R. Y., and Zhang, Y. H.: Submicron aerosol analysis and organic source apportionment in an urban atmosphere in Pearl River Delta of China using high-resolution aerosol mass spectrometry, J. Geophys. Res.-Atmos., 116, D12304, doi:10.1029/2010JD014566, 2011.

Hennigan, C. J., Sullivan, A. P., Collett, J. L., and Robinson, A. L.: Levoglucosan stability in biomass burning particles exposed to hydroxyl radicals, Geophys. Res. Lett., 37, L09806, doi:10.1029/2010g1043088, 2010.

Hoffer, A., Gelencsér, A., Guyon, P., Kiss, G., Schmid, O., Frank, G. P., Artaxo, P., and Andreae, M. O.: Optical properties of humic-like substances (HULIS) in biomass-burning aerosols, Atmos. Chem. Phys., 6, 3563-3570, doi:10.5194/acp-6-3563-2006, 2006.

Hoffmann, D., Tilgner, A., Iinuma, Y., and Herrmann, H.: Atmospheric Stability of Levoglucosan: A Detailed Laboratory and Modeling Study, Environ. Sci. Technol., 44, 694-699, doi:10.1021/Es902476f, 2010.

Huang, X.-F., He, L.-Y., Hu, M., Canagaratna, M. R., Kroll, J. H., Ng, N. L., Zhang, Y.-H., Lin, Y., Xue, L., Sun, T.-L., Liu, X.-G., Shao, M., Jayne, J. T., and Worsnop, D. R.: Characterization of submicron aerosols at a rural site in Pearl River Delta of China using an Aerodyne High-Resolution Aerosol Mass Spectrometer, Atmos. Chem. Phys., 11, 1865-1877, doi:10.5194/acp-11-18652011, 2011.

Hudson, P. K., Murphy, D. M., Cziczo, D. J., Thomson, D. S., de Gouw, J. A., Warneke, C., Holloway, J., Jost, J. R., and Hubler, G.: Biomass-burning particle measurements: Characteristic composition and chemical processing, J. Geophys. Res.Atmos., 109, D23S57, doi:10.1029/2003JD004398, 2004.

Huffman, J. A., Jayne, J. T., Drewnick, F., Aiken, A. C., Onasch, T., Worsnop, D. R., and Jimenez, J. L.: Design, modeling, optimization, and experimental tests of a particle beam width probe for the aerodyne aerosol mass spectrometer, Aerosol Sci. Technol., 39, 1143-1163, doi:10.1080/02786820500423782, 2005.

Iinuma, Y., Bruggemann, E., Gnauk, T., Muller, K., Andreae, M. O., Helas, G., Parmar, R., and Herrmann, H.: Source characterization of biomass burning particles: The combustion of selected European conifers, African hardwood, savanna grass, and German and Indonesian peat, J. Geophys. Res.-Atmos., 112, D08209, doi:10.1029/2006jd007120, 2007.

Iinuma, Y., Engling, G., Puxbaum, H., and Herrmann, H.: A highly resolved anion-exchange chromatographic method for determination of saccharidic tracers for biomass combustion and primary bio-particles in atmospheric aerosol, Atmos. Environ., 43, 13671371, doi:10.1016/j.atmosenv.2008.11.020, 2009.

Iinuma, Y., Boge, O., Grafe, R., and Herrmann, H.: MethylNitrocatechols: atmospheric tracer compounds for biomass burning secondary organic aerosols, Environ. Sci. Technol., 44, 8453-8459, doi:10.1021/Es102938a, 2010.
Jalava, P. I., Salonen, R. O., Nuutinen, K., Pennanen, A. S., Happo, M. S., Tissari, J., Frey, A., Hillamo, R., Jokiniemi, J., and Hirvonen, M. R.: Effect of combustion condition on cytotoxic and inflammatory activity of residential wood combustion particles, Atmos. Environ., 44, 1691-1698, doi:10.1016/j.atmosenv.2009.12.034, 2010.

Johansson, L. S., Leckner, B., Gustavsson, L., Cooper, D., Tullin, C., and Potter, A.: Emission characteristics of modern and old-type residential boilers fired with wood logs and wood pellets, Atmos. Environ., 38, 4183-4195, doi:10.1016/j.atmosenv.2004.04.020, 2004.

Kozinski, J. A. and Saade, R.: Effect of biomass burning on the formation of soot particles and heavy hydrocarbons. An experimental study, Fuel, 77, 225-237, 1998.

Krecl, P., Hedberg Larsson, E., Ström, J., and Johansson, C.: Contribution of residential wood combustion and other sources to hourly winter aerosol in Northern Sweden determined by positive matrix factorization, Atmos. Chem. Phys., 8, 3639-3653, doi:10.5194/acp-8-3639-2008, 2008

Lanz, V. A., Alfarra, M. R., Baltensperger, U., Buchmann, B., Hueglin, C., and Prévôt, A. S. H.: Source apportionment of submicron organic aerosols at an urban site by factor analytical modelling of aerosol mass spectra, Atmos. Chem. Phys., 7, 1503-1522, doi:10.5194/acp-7-1503-2007, 2007.

Lanz, V. A., Prévôt, A. S. H., Alfarra, M. R., Weimer, S., Mohr, C., DeCarlo, P. F., Gianini, M. F. D., Hueglin, C., Schneider, J., Favez, O., D’Anna, B., George, C., and Baltensperger, U.: Characterization of aerosol chemical composition with aerosol mass spectrometry in Central Europe: an overview, Atmos. Chem. Phys., 10, 10453-10471, doi:10.5194/acp-10-10453-2010, 2010.

Lee, S., Schauer, J. J., Sheesley, R. J., Naeher, L. P., Meinardi, S., Blake, D. R., Edgerton, E. S., Russell, A. G., Clements, M., and Baumann, K.: Gaseous and particulate emissions from prescribed burning in Georgia, Environ. Sci. Technol., 39, 90499056, doi:10.1021/es0515831, 2005.

Lewtas, J.: Air pollution combustion emissions: Characterization of causative agent and mechanisms associated with cancer, reproductive, and cardiovasular effects, Mutation Research - Reviews in Mutation Research, 636, 95-133, doi:10.1016/j.mrrev.2007.08.003, 2007.

Lin, P., Engling, G., and Yu, J. Z.: Humic-like substances in fresh emissions of rice straw burning and in ambient aerosols in the Pearl River Delta Region, China, Atmos. Chem. Phys., 10, 64876500, doi:10.5194/acp-10-6487-2010, 2010.

Löschau, G.: Luftqualität in Seiffen - Ergebnisse der Sondermessung im sächsischen Luftgütemessnetz in den Jahren 2005 und 2006. Technical Report, Landesamt für Umwelt und Geologie, Dresden, Ref. 22, Az. 22-8826.8880/8829, 2007 (in German).

Mandalakis, M., Gustafsson, O., Alsberg, T., Egeback, A. L., Reddy, C. M., Xu, L., Klanova, J., Holoubek, I., and Stephanou, E. G.: Contribution of biomass burning to atmospheric polycyclic aromatic hydrocarbons at three European background sites, Environ. Sci. Technol., 39, 2976-2982, doi:10.1021/Es048184v, 2005.

Marchand, N., Besombes, J. L., Chevron, N., Masclet, P., Aymoz, G., and Jaffrezo, J. L.: Polycyclic aromatic hydrocarbons (PAHs) in the atmospheres of two French alpine valleys: sources and temporal patterns, Atmos. Chem. Phys., 4, 11671181, doi:10.5194/acp-4-1167-2004, 2004. 
Matthew, B. M., Middlebrook, A. M., and Onasch, T. B.: Collection efficiencies in an Aerodyne Aerosol Mass Spectrometer as a function of particle phase for laboratory generated aerosols, Aerosol Sci. Technol., 42, 884-898, doi:10.1080/02786820802356797, 2008.

Mayol-Bracero, O. L., Guyon, P., Graham, B., Roberts, G., Andreae, M. O., Decesari, S., Facchini, M. C., Fuzzi, S., and Artaxo, P.: Water-soluble organic compounds in biomass burning aerosols over Amazonia - 2. Apportionment of the chemical composition and importance of the polyacidic fraction, J. Geophys. Res.-Atmos., 107, 8091, doi:10.1029/2001jd000522, 2002.

Mohr, C., Huffman, J. A., Cubison, M. J., Aiken, A. C., Docherty, K. S., Kimmel, J. R., Ulbrich, I. M., Hannigan, M., and Jimenez, J. L.: Characterization of primary organic aerosol emissions from meat cooking, trash burning, and motor vehicles with HighResolution Aerosol Mass Spectrometry and comparison with Ambient and chamber observations, Environ. Sci. Technol., 43, 2443-2449, doi:10.1021/es8011518, 2009.

Mukai, H. and Ambe, Y.: Characterization of a Humic Acid-Like brown substance in airborne particulate matter and tentative identification of its origin, Atmos. Environ., 20, 813-819, 1986.

Müller, K., Birmili, W., Bruggemann, E., Gnauk, T., Iinuma, Y., Poulain, L., Weinhold, K., Löschau, G., and Herrmann, H.: Particulate wood combustion emissions in a Saxonian spa town, Gefahrst. Reinhalt. L., 70, 493-499, 2010.

Naeher, L. P., Brauer, M., Lipsett, M., Zelikoff, J. T., Simpson, C. D., Koenig, J. Q., and Smith, K. R.: Woodsmoke health effects: A review, Inhal. Toxicol., 19, 67-106, doi:10.1080/08958370600985875, 2007.

Neusüß, C., Pelzing, M., Plewka, A., and Herrmann, H.: A new analytical approach for size-resolved speciation of organic compounds in atmospheric aerosol particles: Methods and first results, J. Geophys. Res.-Atmos., 105, 4513-4527, doi:10.1029/1999JD901038, 2000.

Ng, N. L., Canagaratna, M. R., Zhang, Q., Jimenez, J. L., Tian, J., Ulbrich, I. M., Kroll, J. H., Docherty, K. S., Chhabra, P. S., Bahreini, R., Murphy, S. M., Seinfeld, J. H., Hildebrandt, L., Donahue, N. M., DeCarlo, P. F., Lanz, V. A., Prévôt, A. S. H., Dinar, E., Rudich, Y., and Worsnop, D. R.: Organic aerosol components observed in Northern Hemispheric datasets from Aerosol Mass Spectrometry, Atmos. Chem. Phys., 10, 46254641, doi:10.5194/acp-10-4625-2010, 2010.

Nolte, C. G., Schauer, J. J., Cass, G. R., and Simoneit, B. R. T.: Highly polar organic compounds present in wood smoke and in the ambient atmosphere, Environ. Sci. Technol., 35, 1912-1919, 2001.

Ostro, B., Feng, W. Y., Broadwin, R., Green, S., and Lipsett, M.: The effects of components of fine particulate air pollution on mortality in California: Results from CALFINE, Environ. Health Perspect., 115, 13-19, doi:10.1289/Ehp.9281, 2007.

Paatero, P. and Tapper, U.: Positive Matrix Factorization - a Nonnegative Factor Model with Optimal Utilization of ErrorEstimates of Data Values, Environmetrics, 5, 111-126, 1994.

Paatero, P., Hopke, P. K., Song, X. H., and Ramadan, Z.: Understanding and controlling rotations in factor analytic models, Chemom. Intell. Lab. Syst., 60, 253-264, 2002.

Pope, C. A.: Epidemiology of fine particulate air pollution and human health: Biologic mechanisms and who's at risk?, Environ. Health Perspect., 108, 713-723, 2000.
Rogge, W. F., Hildemann, L. M., Mazurek, M. A., Cass, G. R., and Simoneit, B. R. T.: Sources of fine organic aerosol. 9. Pine, oak and synthetic log combustion in residential fireplaces, Environ. Sci. Technol., 32, 13-22, 1998.

Saarikoski, S. K., Sillanpaa, M. K., Saarnio, K. M., Hillamo, R. E., Pennanen, A. S., and Salonen, R. O.: Impact of biomass combustion on urban fine particulate matter in Central and Northern Europe, Water Air Soil Poll., 191, 265-277, doi:10.1007/s11270008-9623-1, 2008.

Sandradewi, J., Prevot, A. S. H., Weingartner, E., Schmidhauser, R., Gysel, M., and Baltensperger, U.: A study of wood burning and traffic aerosols in an Alpine valley using a multi-wavelength Aethalometer, Atmos. Environ., 42, 101-112, doi:10.1016/j.atmosenv.2007.09.034, 2008.

Schauer, J. J. and Cass, G. R.: Source apportionment of wintertime gas-phase and particle-phase air pollutants using organic compounds as tracers, Environ. Sci. Technol., 34, 1821-1832, 2000.

Schneider, J., Weimer, S., Drewnick, F., Borrmann, S., Helas, G., Gwaze, P., Schmid, O., Andreae, M. O., and kirchner, U.: Mass spectrometric analysis and aerodynamic properties of various types of combustion-related aerosol particles, Int. J. Mass. Spectrom., 258, 37-49, doi:10.1016/j.ijms.2006.07.008, 2006.

Sehlstedt, M., Dove, R., Boman, C., Pagels, J., Swietlicki, E., Londahl, J., Westerholm, R., Bosson, J., Barath, S., Behndig, A. F., Pourazar, J., Sandstrom, T., Mudway, I. S., and Blomberg, A.: Antioxidant airway responses following experimental exposure to wood smoke in man, Particle and Fibre Toxicology, 7, 21, doi:10.1186/1743-8977-7-21, 2010.

Sheesley, R. J., Kruså, M., Krecl, P., Johansson, C., and Gustafsson, Ö.: Source apportionment of elevated wintertime PAHs by compound-specific radiocarbon analysis, Atmos. Chem. Phys., 9, 3347-3356, doi:10.5194/acp-9-3347-2009, 2009

Sun, J. Y., Zhang, Q., Canagaratna, M. R., Zhang, Y. M., Ng, N. L., Sun, Y. L., Jayne, J. T., Zhang, X. C., Zhang, X. Y., and Worsnop, D. R.: Highly time- and size-resolved characterization of submicron aerosol particles in Beijing using an Aerodyne Aerosol Mass Spectrometer, Atmos. Environ., 44, 131-140, doi:10.1016/j.atmosenv.2009.03.020, 2010.

Sun, Y., Zhang, Q., Macdonald, A. M., Hayden, K., Li, S. M., Liggio, J., Liu, P. S. K., Anlauf, K. G., Leaitch, W. R., Steffen, A., Cubison, M., Worsnop, D. R., van Donkelaar, A., and Martin, R. V.: Size-resolved aerosol chemistry on Whistler Mountain, Canada with a high-resolution aerosol mass spectrometer during INTEX-B, Atmos. Chem. Phys., 9, 3095-3111, doi:10.5194/acp9-3095-2009, 2009.

Takegawa, N., Miyakawa, T., Watanabe, M., Kondo, Y., Miyazaki, Y., Han, S., Zhao, Y., van Pinxteren, D., Bruggemann, E., Gnauk, T., Herrmann, H., Xiao, R., Deng, Z., Hu, M., Zhu, T., and Zhang, Y.: Performance of an Aerodyne Aerosol Mass Spectrometer (AMS) during Intensive Campaigns in China in the Summer of 2006, Aerosol Sci. Technol., 43, 189-204, doi:10.1080/02786820802582251, 2009.

Ulbrich, I. M., Canagaratna, M. R., Zhang, Q., Worsnop, D. R., and Jimenez, J. L.: Interpretation of organic components from Positive Matrix Factorization of aerosol mass spectrometric data, Atmos. Chem. Phys., 9, 2891-2918, doi:10.5194/acp-9-2891-2009, 2009.

Weimer, S., Alfarra, M. R., Schreiber, D., Mohr, M., Prévôt, A. S. H., and Baltensperger, U.: Organic aerosol mass spectral 
signatures from wood-burning emissions: Influence of burning conditions and wood type, J. Geophys. Res., 113, D10304, doi:10.1029/2007JD009309, 2008.

Zelikoff, J. T., Chen, L. C., Cohen, M. D., and Schlesinger, R. B.: The toxicology of inhaled woodsmoke, Journal of Toxicology and Environmental Health-Part B-Critical Reviews, 5, 269-282, doi:10.1080/10937400290070062, 2002.
Zhang, Q., Alfarra, M. R., Worsnop, D. R., Allan, J. D., Coe, H., Canagaratna, M. R., and Jimenez, J. L.: Deconvolution and quantification of hydrocarbon-like and oxygenated organic aerosols based on aerosol mass spectrometry, Environ. Sci. Technol., 39, 4938-4952, doi:10.1021/es0485681, 2005a.

Zhang, Q., Worsnop, D. R., Canagaratna, M. R., and Jimenez, J. L.: Hydrocarbon-like and oxygenated organic aerosols in Pittsburgh: insights into sources and processes of organic aerosols, Atmos. Chem. Phys., 5, 3289-3311, doi:10.5194/acp-5-32892005, 2005b. 